This is a self-archived - parallel published version of this article in the publication archive of the University of Vaasa. It might differ from the original.

\title{
Impact of external assurance on corporate climate change disclosures: new evidence from Finland
}

Author(s): Dutta, Probal; Dutta, Anupam

Title: $\quad$ Impact of external assurance on corporate climate change disclosures : new evidence from Finland

Year: $\quad 2020$

Version: Accepted manuscript

Copyright C)2020 Emerald Publishing Limited. This manuscript version is made available under the Creative Commons Attribution-NonCommercial 4.o International (CC BY-NC 4.0) license, https://creativecommons.org/licenses/by-nc/4.0/

Please cite the original version:

Dutta, P. \& Dutta, A. (2020). Impact of external assurance on corporate climate change disclosures : new evidence from Finland. Journal of Applied Accounting Research Vol. ahead-of-print No. ahead-of-print. https://doi.org/10.1108/JAAR-08-2020-0162 


\title{
Impact of external assurance on corporate climate change disclosures: new evidence from Finland
}

\begin{abstract}
Purpose: The purpose of this research is to examine the impact of external assurance on the level of voluntary corporate climate change disclosures by Finnish firms.

Design/methodology/approach: The sample of this study includes 228 firm-year observations over the period 2008-2015 for listed Finnish companies that have issued sustainability reports and responded to the Carbon Disclosure Project (CDP) questionnaire at least once during the sample period. We conduct a panel regression analysis to study the afore-mentioned linkage. In addition, the Tobit regression model is also estimated to check the robustness of our findings.
\end{abstract}

Findings: The findings suggest that assurance has a highly significant positive impact on the level of corporate climate change disclosures even after controlling for the effect of a number of control variables. Moreover, among the control variables, firm size and asset age are found to have significant effect on the extent of carbon emissions disclosure. Furthermore, the additional analysis reveals that the type of assurance providers (accounting firms vs non-accounting firms) and the type of financial auditors (Big4 financial auditors vs nonBig4 financial auditors) do not influence the level of climate change disclosure of assured companies.

Research limitations/implications: This research is subject to certain limitations. First, the source of the data used in this research is the CDP database which has limitations in that it is a voluntary disclosure process where all the observations collected are self-reported by the responding firms. This may bias the reported findings. Second, our sample includes only listed companies and hence the results might have limited explanatory capacity for unlisted firms. 
Practical implications: By using the results of this research, corporate managers will be able to reduce the information asymmetry between various stakeholders and them through disclosure of accurate, reliable and credible environmental information. Such disclosures will, in turn, allow socially responsible investors to choose eco-friendly investments and will thus enable them to make appropriate investment decisions.

Originality/value: Research on the external assurance-corporate climate change disclosure nexus is scarce. This study addresses this gap in the nonfinancial disclosure assurance literature by demonstrating that external assurance increases the level of voluntary corporate climate change disclosure. Drawing on stakeholder-agency theory, this study views external assurance as a monitoring structure that potentially curbs the monitoring problem between corporate managers and other stakeholders and increases the amount of climate change disclosures making a possible avenue for the reduction of the information asymmetry between them.

Keywords: External assurance; Climate change disclosure; Stakeholder-agency theory; Monitoring structure; Environmental disclosure; CDP. 


\section{Introduction}

Corporate climate change disclosure practices are a subset of corporate environmental disclosure practices (Haque \& Deegan, 2010; Luo, 2019; Stanny \& Ely, 2008). Corporate climate change disclosure has become particularly important as it can meet the information-need of various stakeholder groups, who are increasingly demanding that companies publicly disclose the impacts of their business practices on climate change (Cotter \& Najah, 2011; Haque \& Deegan, 2010). For instance, Stanny \& Ely (2008, p. 338) report that in October 2007, a group of stakeholders (consisting of state officials and institutional investors representing more than 1.5 trillion USD in assets) petitioned the US Securities and Exchange Commission to issue an interpretive release 'clarifying that material climate-related information must be included in corporate disclosures under existing law'; Stanny and Ely (2008, p. 338) inform further that this group called not only for disclosure by high-emission firms "but also for low-emission firms to disclose information about estimated future physical and regulatory risks from climate change". This incident corroborates the growing concern over the issue of climate change as well as the development of environmental consciousness of the public. T

he plausible reason for the growing concern over the issue of climate change may be the numerous impacts of climate change on ecosystems and subsequently on human lives (Giannarakis et al., 2017). Climate change is exacerbated by global warming (Jones, 2010) and global warming is believed to be principally caused by greenhouse gas (GHG) emissions (Giannarakis et al., 2017; Liao et al., 2015). Corporations are expected to play an important role in stabilizing climate change (Hossain et al., 2017) as corporate business and assets are in large part responsible for increasingly severe climate change (Liao et al., 2015). The growing public concern over the issue of climate change has led firms to adopt environment-friendly strategies 
(e.g., initiation of green practices) contributing to the global target of reducing GHG emissions (Giannarakis et al., 2017) and created the demand for increased information transparency for the climate change issue (Liao et al., 2015); failure to meet this demand on the part of organizations will prevent various stakeholders from assessing the risks that climate change poses to the respective organizations (Haque \& Deegan, 2010). In order to meet the information-need of stakeholders, companies are voluntarily and increasingly, in their annual reports or stand-alone environmental or sustainability reports, disclosing environmental information that also includes climate change-related information (e.g., climate change policy, amount of GHG emissions, initiatives for reducing GHG emissions, initiatives for improving energy efficiency, use of clean energy sources such as biofuel etc.) (Braam et al., 2016; Giannarakis et al., 2017).

Braam et al. (2016) claim that companies may use corporate environmental disclosure as a management tool and argue that through disclosure of environmental information, good environmental performers may send signals to stakeholders about their success in environmental performance (EP) and seriousness towards sustainable development; on the other hand, poor environmental performers may seek legitimacy of their business activities through such disclosures. Further, Braam et al. (2016) contend that companies may try to change public perceptions rather than disclose actual EP by providing environment-related information; for example, companies with poor EP may self-servingly prefer to disclose information about only good EP rather than provide information on both good and bad EP in a balanced report (Braam \& Peeters, 2018, Cho et al., 2012). The results of the study undertaken by Braam et al. (2016) confirm that companies with poorer environmental performance in terms of GHG emissions tend to disclose more environmental information than companies that emit lower amount of greenhouse gases in order to gain legitimacy. The tendency of companies to manage public 
perceptions rather than reveal actual EP through environmental disclosures raises a great concern about the accuracy, reliability and credibility of the EP information disclosed (Braam et al., 2016). In response to such concern, companies are increasingly inclined to have their environmental information assured by independent assurance providers (Braam \& Peeters, 2018; Junior et al., 2014).

As far as assurance of corporate climate change disclosures is concerned, there is an increased international demand for such assurance; the release of ISAE 3410 Assurance Engagements on Greenhouse Gas Emissions by the International Auditing and Assurance Standards Board (IAASB) (International Federation of Accountants (IFAC), 2012) and the development of carbon pricing and emission trading schemes (ETS)-such as the European Union ETS, New Zealand ETS and the Australian Carbon Pricing Mechanism have escalated the demand for verification and assurance of carbon-related disclosures (Green \& Taylor, 2013). Moreover, previous studies confirm that independent third-party assurance enhances the credibility of non-financial disclosures (e.g., corporate climate change disclosures) and subsequently builds corporate reputation (Giannarakis et al., 2018; Moroney et al., 2012; Pflugrath et al., 2011; Reimsbach et al., 2018; Simnett et al., 2009). Giannarakis et al. (2018) suggest that independent assessment of environmental initiatives prevents companies from manipulating the dissemination of climate change information; furthermore, external assurance plays an important role in the evaluation of risks and concerns relating to climate change and thus improves environmental reporting transparency on the adoption of climate change mitigation strategies. Despite the importance of and the growing demand for external assurance of GHG emissions information, there has been little research investigating the relationship between external assurance and the level of climate change-related disclosures (Giannarakis et al., 2018). This study, using a sample of 228 
observations from 37 listed Finnish companies during the period 2008-2015, addresses this lacuna by examining the impact of external assurance on corporate climate change disclosures in a voluntary context.

For this research, Finland remains the geographical area of interest for two reasons. First, Finland has an active role in climate change policy. Climate change policies are being made at the international, European Union (EU) and national levels. At the international level, Finland has ratified the United Nations Framework Convention on Climate Change (UNFCCC) in 1994 and the Kyoto Protocol (KP) in 2002 together with other EU countries. The KP supplements the UNFCCC and specifies the obligations in decreasing GHG emissions of the countries that are parties to it. In addition, Finland being a member state of the EU is also committed to the EU's policy objectives on climate change. Furthermore, Finland has a strong national climate change policy which is based on international and EU climate change policies. The national Climate Change Act (609/2015) of Finland entered into force on June 1, 2015 and was followed by the introduction of the first medium-term climate change policy plan "Towards Climate-Smart Dayto-Day Living" on September 14, 2017. The medium-term climate change policy plan was adopted by the Parliament in March 2018. The national Climate Change Act (609/2015) has set the long-term target of reducing all types of GHG emissions by at least $80 \%$ by 2050 , compared to 1990; on the other hand, the medium-term climate change policy plan aims at reducing GHG emissions by $16 \%$ in the non-emissions trading sectors (compared to 1990) and by $21 \%$ in the emissions trading sectors (compared to 2005) by $2020^{1}$. Every year Finland obligatorily reports to the European Commission and the UNFCCC Secretariat on progress made in the reduction of GHG emissions.

\footnotetext{
${ }^{1}$ This information is sourced from http://www.ym.fi/enUS/The_environment/Climate_and_air/Mitigation_of_climate_change/National_climate_policy.
} 
Second, Finland is severely affected by global climate change ${ }^{2}$. Finland's climate is warming at a faster rate; within the last hundred years, the country has experienced an increase in the average temperature by one degree Celsius, mainly due to global climate change whereas the global average temperature is $0.85^{0} \mathrm{C}$ higher than it was in the late $19^{\text {th }}$ century ${ }^{3}$. According to the Arctic Climate Impact Assessment (ACIA), the annual average temperature in the Arctic region (including Finland) has increased at almost twice the rate of the rest of the world. As a consequence, in Finland by 2025 the average temperature is projected to rise slightly over $2{ }^{\circ} \mathrm{C}$ relative to 1961-1990. The analysis also indicates that the average temperature is projected to rise by 4 to $6{ }^{\circ} \mathrm{C}$ and average precipitation by 15 to 25 per cent by the 2080s compared to the period 1961-1990. Temperatures will rise the most in winter and precipitation also increases especially in winter. Forsius et al. (2013), for example, also document that climate change predictions for Finland indicate an increase in precipitation of $5-40 \%$ and in air temperature of $2-78 \mathrm{C}$ by the $2080 \mathrm{~s}^{4}$. The impacts of changes in the climate are already visible in Finland ${ }^{2}$. For example, many northern and southern species that inhabit Finland are affected by climate change; in winter, many snow and ice-dependent species are at risk of disappearing altogether and in the spring and summer, the probability of forest fires increases ${ }^{1}$; there is also a probability that river, lake and sea ice will break up earlier ${ }^{5}$. Besides, Palsa mires in Lapland may be destroyed and hence, snow-related winter tourism suffers in southern Finland. In addition, need for energy for cooling of buildings increases in summer as well.

\footnotetext{
${ }^{2}$ This information is sourced from http://www.ymparistotiedonfoorumi.fi/puheenvuorot/ilmastonmuutos-haastaa-perinteisenluonnonsuojelun/.

${ }^{3}$ This information is sourced from https://ec.europa.eu/clima/change/causes_en.

${ }^{4}$ In order to lessen the adverse impact of traditional energy usage on climate change, the Finnish government policy aims to increase the use of renewable energy to 38\% of energy consumption by 2020 and to $60 \%$ by 2050 (Climate and Energy Strategy 2008).

${ }^{5}$ This information is sourced from http://www.environment.fi/enUS/Maps and statistics/The state of the environment indicators/Climate change and energy/Average temperature in Finla nd_up_by_one(28736).
} 
This paper has several contributions. First, it exclusively focuses on the impact of external assurance on the level of corporate climate change disclosure in a voluntary context. Climate change is a global phenomenon with a long-term and probably perpetual impact (Datt et al., 2019; Lash \& Wellington, 2007). Corporate business and assets are in large part responsible for increasingly severe climate change (Liao et al., 2015). The phenomenon of climate change is mainly caused by GHG emissions (Giannarakis et al., 2017; Liao et al., 2015) that are subject to different regulations (Luo, 2019). All these issues differentiate climate change from other environmental problems companies contribute to and make disclosure of climate change-related information unique among environmental disclosures (Luo, 2019). In addition, companies increasingly signal their green credentials through climate change disclosures (Chithambo \& Tauringana, 2014; Rankin et al., 2011; Peters \& Romi, 2015). Furthermore, the development of a separate carbon assurance standard (titled ISAE 3410 Assurance on a Greenhouse Gas Statement) by the IFAC through its International Auditing and Assurance Standards Board (IAASB), emphasizes the probability that corporate climate change disclosure and assurance of such disclosure may become a standard practice in a low-carbon economy and facilitate stakeholders' decision-making (Datt et al., 2019). Nevertheless, prior studies have not paid much attention to the linkage between carbon assurance and the level of voluntary climate change disclosure and have principally examined the effect of external assurance on the broader subject-matters of sustainability or environmental disclosure (e.g., Hassan et al., 2019; Braam et al., 2016; Moroney et al., 2012). Our study fills this gap in the existing literature.

Second, this study addresses the need for further research highlighted by Giannarakis et al. (2018), the only study that examines the effect of external assurance (in addition to other factors such as government ownership and corporate environmental performance) on corporate climate 
change disclosure. Using cross-sectional data of 2014, Giannarakis et al. (2018) find a positive influence of external assurance and government ownership and a negative effect of corporate environmental performance on climate change disclosure. While these findings provide important insights into the determinants of corporate voluntary climate change disclosure, Giannarakis et al. (2018) underline the importance of longitudinal research to discover any potentially continued impact of external assurance on corporate carbon disclosures over a longer time period. This empirical research complements the work of Giannarakis et al. (2018) by using panel data covering a longer time period in order to understand whether external assurance has a sustained influence on the dissemination level of climate change-related information when multiple time periods are considered. Furthermore, this research supplements Giannarakis et al. (2018) by investigating the impact of type of assurance provider (professional accounting firms or consulting firms) and type of financial auditor (Big4 or non-Big4 accounting firms) on corporate voluntary carbon disclosures.

Third, based on authors' knowledge this is the initial study to use, as a proxy for the level of corporate climate change disclosures, both numeric and letter scores awarded (by the Carbon Disclosure Project (CDP)) to companies responding to a standard questionnaire set by the CDP. The CDP uses the questionnaire in order to conduct a survey investigating corporate carbon emissions. In 2016, the CDP adopted a new scoring methodology and started awarding only letter scores instead of both numeric and letter scores (as it used to award till 2015) to companies that participated in the survey. Before 2016, numeric scores would merely measure corporate climate change disclosures whereas letter scores were a measure of both corporate environmental performance in terms of corporate carbon emissions and corporate climate change disclosures (CDP, 2008; Guenther et al., 2016). The letter score introduced in 2016 measures both corporate 
carbon performance and climate change disclosures (CDP, 2016). Previous studies have considered either numeric scores (e.g., Luo, 2019) or letter scores (e.g., Giannarakis et al., 2018) awarded before 2016 as a proxy for the level of corporate climate change disclosures in their analyses. In contrast to earlier studies, this empirical research uses both numeric scores (for the period 2008-2015) and letter scores (for the period 2016-2018 in the additional analysis).

Fourth, on the theoretical front, this study adds to the sustainability assurance literature by employing stakeholder-agency theory to understand the impact of external assurance on corporate voluntary climate change reporting. Tyson \& Adams (2020) suggest that prior research has applied several organizational theories (namely, agency, contingency, gatekeeping, institutional, legitimacy, stakeholder, strong structuration, and transformational leadership) to provide insights into the phenomenon of sustainability assurance. But drawing on stakeholderagency theory, this empirical work views, for the first time (to the best of the authors' knowledge), external assurance as a monitoring structure (the concept developed by Hill \& Jones (1992) in their proposed theory) in order to understand its impact on the extent of corporate voluntary climate change disclosure.

Finally, the results of this Finnish study may be valid for other EU countries given that all the EU countries are affected by the EU's recommendations for fighting climate change. Besides some EU countries have financial markets and legal systems similar to those of Finland as well.

This paper proceeds as follows. The next section attempts to contain a comprehensive literature review. Section 3 discusses the relevant theory for this research and subsequently, the hypothesis is developed. Section 4 outlines the research methods. Our empirical results are discussed in Section 5. The final section concludes the paper. 


\section{Literature Review}

Recent years have witnessed a worldwide increase in the publication of sustainability reports (Radhouane et al., 2020; Sellami et al., 2019; Jones et al., 2015; KPMG, 2013). The growth in the publication of such reports can be attributed to stakeholders' increasing interest in sustainability information (of which climate change-related information is a part) (Datt et al., 2019; Wong et al., 2016) and the consequent awareness of companies of their responsibility for sustainability (Gillet-Monjarret, 2018; Jones et al., 2015). Keeping pace with the growing public interest in companies' commitment towards the broader issues of sustainability, the societal concern regarding global climate change (resulting from the increase in average temperature of the Earth's surface due to the concentration of GHGs in the atmosphere) has also escalated because of its potential adverse impact on human life and the natural environment (Giannarakis et al., 2017; Martinov-Bennie, 2012) and such concern has emphasized the need for disclosure of climate change-related information by companies (Datt et al., 2019; Zhou et al., 2016; MartinovBennie, 2012; Thornton \& Hsu, 2001). In addition, corporate climate change-related information has become extremely important to stakeholders' decision-making processes (Datt et al., 2019; Green et al., 2017; Stanny \& Ely, 2008; Thornton \& Hsu, 2001). This has led to an increase in both voluntary and mandatory carbon emissions disclosure (Green et al., 2017).

However, stakeholders tend to mistrust the disclosed information relating to climate change because the discretionary nature of carbon emissions disclosure, managerial incentives to manipulate such disclosure and the lack of an internationally recognized protocol make the quality and reliability of corporate climate change-related disclosures questionable (Datt et al., 2019; Kolk et al., 2008). The existing literature suggests that the procurement of external assurance (by an independent third party) of nonfinancial information (including climate change- 
related information along with other sustainability information) adds credibility and reliability to the disclosed information and enhances stakeholders' confidence therein (Wong et al., 2016; Zhou et al., 2016; Gillet-Monjarret, 2012; Manetti \& Toccafondi, 2012; Moroney et al., 2012; Pflugrath et al., 2011). Hence, in order to increase stakeholders' trust in the credibility of disclosed nonfinancial information (Radhouane et al., 2020; Clarkson et al., 2019; Datt et al., 2019; Zhou et al., 2016; Gillet-Monjarret, 2018, 2015; Green \& Li, 2012; Huggins et al., 2011; Simnett et al., 2009), companies are increasingly procuring assurance of two types of nonfinancial disclosure: assurance of the broad-ranging subject matter of sustainability disclosure and assurance of an organization's disclosure of climate change-related information (Zhou et al., 2016; Cohen \& Simnett, 2015).

The escalating demand for external assurance of nonfinancial disclosure has attracted much research attention that has recently led to an increase in the number of studies exploring such kind of assurance (Rossi \& Tarquinio, 2017). Several of these studies have examined the impact of external assurance on firm valuation and cost of equity capital of disclosing firms (e.g., Radhouane et al., 2020; Clarkson et al., 2019; Hassan et al., 2019; Weber, 2018; Fazzini \& Maso, 2016; Cho et al., 2014 and so on). On the contrary, only a handful of studies (e.g., Hassan et al., 2019; Giannarakis et al., 2018; Braam et al., 2016; Moroney et al., 2012) have investigated the effect of external assurance on the level of dissemination of nonfinancial information (that includes climate change-related information and other sustainability information).

Although the empirical research on the effect of external assurance on firm valuation and cost of equity capital has produced mixed results, the outcomes of the studies examining the impact of 
external assurance on the disclosure of nonfinancial information have converged confirming that external assurance positively affects the level of nonfinancial disclosure.

As far as corporate nonfinancial information is concerned, corporate climate change-related information differs from other sustainability information (e.g., information relating to environmental issues other than the issue of climate change) because it includes GHG information, which is more similar (when compared to other nonfinancial information) to financial information due to its quantifiable nature (Zhou et al., 2016). Given the uniqueness and distinctiveness of corporate climate change-related information and the growth in demand for assurance of such information, the IAASB issued a separate assurance standard titled ISAE 3410 Assurance Engagements on Greenhouse Gas Emissions (IFAC, 2012) even in the presence of ISAE 3000 (Revised) Assurance Engagements Other Than Audits or Reviews of Historical Financial Information, which is applicable to the assurance of general sustainability information (Zhou et al., 2016). The ISAE 3410 emphasizes the need for the carrying out of the assurance of carbon emissions disclosure either as part of the assurance of a sustainability report/annual report or on a standalone GHG report (Datt et al., 2019).

It is noteworthy that regardless of the growth in the demand for assurance of carbon emissions disclosure and the release of the ISAE 3410 by the IAASB, only one study (Giannarakis et al., 2018) has been found inquiring into the impact of external assurance on the level of corporate climate change disclosure, while other studies (Hassan et al., 2019; Braam et al., 2016; Moroney 
et al., 2012) have examined the effect of external assurance on the level of the broader subject matter of sustainability disclosure or environmental disclosure ${ }^{6}$.

However, Giannarakis et al. (2018) has used cross-sectional data relating to the year 2014 for 215 European companies in order to examine the influence of the broad-ranging environmental assurance on the dissemination level of corporate climate change-related information. The companies studied by Giannarakis et al. (2018) have purchased environmental assurance, which is intended for enhancing the credibility of environmental disclosures, a broader subject matter that includes corporate climate change disclosures (Luo, 2019; Haque \& Deegan, 2010; Stanny \& Ely, 2008). Consequently, in case the environmental assurance process has covered only specific sections of corporate sustainability/environmental/social responsibility reports, it is possible that the assurance scope may have missed out climate change disclosures. Furthermore, the use of cross-sectional data by Giannarakis et al. (2018) demonstrates that external assurance positively affects corporate climate change disclosure level during a single time period; but this result does not confirm that external assurance has a sustained influence on the dissemination level of climate change-related information when multiple time periods are considered. In other words, there is a lack of evidence that the outcome of Giannarakis et al. (2018) holds true over a longer period of time with external assurance impacting the evolution of corporate climate change disclosure (in terms of increase in the quantity of such disclosure) over time.

Hence, a unique opportunity exists to examine the impact of external assurance on the level of carbon emissions disclosure given that external assurance covers, at a minimum, climate change-

\footnotetext{
${ }^{6}$ Due to the growing concern about the issue of climate change, a number of studies have been undertaken analyzing corporate climate change disclosures. These studies broadly fall into two groups: while one group of research has examined the company specific determinants of corporate climate change disclosures, another group of studies has investigated the effect of different corporate governance characteristics on the dissemination of climate change information (Kılıç \& Kuzey, 2019). Table 1 summarizes notable works from both groups. The summaries in Table 1 witness the scarcity of research investigating the impact of voluntary external assurance on the extent of corporate climate change disclosures.
} 
related information. We use panel data covering a period of eight years (2008-2015) and extend the prior research by investigating whether external assurance has a continued effect on the extent of GHG disclosure. Additionally, in order to gain a holistic understanding of the phenomenon of third-party assurance, we inquire into the linkage between the types of assurance provider (accountant versus non-accountant assurance provider and in case the assurance provider is an accounting firm, whether it is a Big4 auditing firm) and the level of corporate climate change disclosure.

Furthermore, it is also evident from the summaries in Table 1 that climate change disclosure practices in Nordic countries remain under-researched, albeit Nordic countries are committed to tackling the climate crisis and advocate for a carbon-neutral society. ${ }^{7}$ Niskala \& Pretes (1995) and Gonzalez-Gonzalez \& Ramírez (2016) assert that the provision of environmental information is dependent on the country under consideration because prior country-specific studies have produced very different results for different countries (e.g., Roberts, 1991; Gray et al., 1995; De Villiers \& Van Staden, 2006). Therefore, Nordic countries deserve special research attention vis-à-vis carbon disclosures and this empirical work, being the first of its kind to exclusively use the Finnish context (Finland being one of the five Nordic countries), addresses this issue.

\section{Theoretical Framework and Hypothesis Development}

A firm has a number of stakeholders that include shareholders, managers, employees, customers, suppliers, lenders, local communities and the general public (Hill \& Jones, 1992). Different stakeholders provide different types of resources to the firm and have different expectations in

\footnotetext{
${ }^{7}$ This Information is sourced from https://www.environment.fi/en$\underline{\text { US/Climate_and_air/Nordic_countries_agree_on_closer_coopera(49105). }}$
} 
exchange of the resources supplied. For example, shareholders provide capital to the firm in the hope that the return on their investment will be maximized; managers and employees serve the firm as human capital and expect fair income and appropriate working conditions in return; local communities provide locations and a local infrastructure to the firm and the general public, through payment of taxes, provides a national infrastructure to the firm and both of these stakeholders want the firm either to enhance the quality of life or to abstain from causing harm to the same through its business activities (Hill \& Jones, 1992). In case stakeholders' interests are not served, they may refuse to provide resources to the firm (e.g., shareholders may sell their shares in case of poor financial performance of the firm; employees and managers may leave the firm if they do not receive fair pay and have appropriate working conditions; the local communities may refuse to provide locations and local infrastructures to the firm for continuing its business operations if its business activities cause damage to the quality of life etc.) and thus threaten its survival.

Stakeholder-agency theory suggests that a firm is a nexus of implicit and explicit contracts among all these stakeholders; managers are unique stakeholders as they are at the center of the nexus of contracts (i.e., managers have contractual relationships with all kinds of stakeholders and thus work as 'agents' for them.) and have a 'direct control over the decision-making apparatus of the firm' (Hill \& Jones, 1992, p. 134). Therefore, it is imperative that managers make strategic decisions and allocate resources in a way that serves the interests of other stakeholders.

Managers also have control over critical information and consequently, they are able to filter or even distort the type of information they release to other stakeholders. This gives rise to an information asymmetry between managers and other stakeholders making it difficult for 
stakeholders to assess whether managers are working to serve their interests. As an obvious response to this situation, stakeholders can undertake their own monitoring of management performance by collecting themselves necessary information on management activities, but the cost of gathering such information may be exorbitant. This is particularly true in a situation termed 'stakeholder diffusion' (Hill \& Jones, 1992), where many individuals or entities constitute a stakeholder group (that excludes managers) and no one of them has control over a substantial portion of the group's total resources. Under these circumstances, no single stakeholder (of the stakeholder group) may be able to sponsor the substantial task of collecting and analyzing information required for the significant reduction of the information asymmetry between managers and stakeholders. Consequently, stakeholders (of the stakeholder group) may have to bear an increased residual loss as stakeholder diffusion confers on managers greater discretionary control over the use of the firm's resources. This situation calls for the establishment of institutional structures, which Hill \& Jones (1992) refer to as 'monitoring structures', for monitoring management performance. Examples of monitoring structures include mandatory requirements of the publication of audited consolidated financial statements by public companies and evolution of non-profit monitoring organizations such as Consumer Watch and labor unions that keep an eye on the extent to which managers serve the interests of certain stakeholders (Hill \& Jones, 1992, p. 140).

As far as dissemination of climate change-related information is concerned, external assurance can serve as a useful control mechanism or 'monitoring structure' (Simnett et al., 2009). Prior studies (e.g., Abdel-khalik, 1993; Blackwell et al., 1998; Dixon et al., 2004; Hasan et al., 2003; Hodge et al., 2009; Simnett et al., 2009) confirm that the assurance function undertaken by an independent third party plays the role of a control mechanism by enhancing the credibility of 
disclosed information and engendering greater trust of stakeholders. Given that climate change disclosures (like other items of sustainability disclosures) are mostly voluntary and guided by limited reporting guidelines (Hodge et al., 2009), stakeholders are likely to lack faith in the disseminated carbon-related information. As such, the third-party verification of the carbon emissions information can restore stakeholders' confidence in the information released.

Moreover, the growing public concern over environmental issues such as climate change has led to the emergence of a number of new stakeholders (e.g., environmental NGOs, green investment funds and green consumers), who pressure companies to become more responsible for the impact of their operations on the natural environment and disseminate credible and reliable information on their environmental activities (Hodge et al., 2009; Moroney et al., 2012). Furthermore, traditional stakeholders such as shareholders have also become concerned about corporate EP along with corporate financial performance, a fact that is evidenced by the growth and emergence of sustainable investment funds and superannuation funds (Van der Laan et al., 2008; Moroney et al., 2012). The existing literature also indicates that independent assurance reduces information asymmetry between managers and other stakeholders (Watts \& Zimmerman, 1986; Wallace, 1987; Carey et al., 2000). Hence external assurance of environmental disclosures can be viewed as a 'monitoring structure' (as referred to by Hill \& Jones, 1992) that aids in reducing the information asymmetry between managers and other stakeholders and thus increases the credibility of the reported environmental information including climate change-related information and engenders stakeholders' confidence. Therefore, stakeholder-agency theory appositely explains the association between external assurance and the extent of corporate climate change disclosures. 
As a monitoring structure, external assurance not only improves the processes of collecting data relating to environmental issues such as carbon emissions (Jones \& Solomon, 2010; O'Dwyer et al., 2011) but also discovers material errors in and omissions of the environmental information prepared including climate change-related information and thus increases the quantity of the disclosed information (Hodge et al., 2009). The standing literature provides evidence in support of the existence of a positive link between external assurance and the level of non-financial disclosures (e.g., environmental disclosures including climate change disclosures, social disclosures etc.): for example, based on a sample of 74 observations of Australian listed companies between 2003 and 2007, Moroney et al. (2012) report a positive association between external assurance and the quality and quantity of environmental disclosure. In addition, Braam et al. (2016) examine the effect of external assurance on the variation in the level of environmental disclosure of Dutch companies for the period from 2009 to 2011 and confirm that external assurance positively affects the level of environmental disclosures.

Furthermore, Giannarakis et al. (2018), using a sample of 215 observations of European companies of Bloomberg European 500 Index for the economic year 2014, investigate the impact of independent assurance on the extent of corporate climate change disclosure. Their results reveal a positive connection between independent assurance and corporate climate change disclosure. As such, independent third-party verification enhances the quality of non-financial disclosures by reducing information asymmetry between managers and other stakeholders (Coram et al., 2009; Moroney et al., 2012) and potentially allows stakeholders to make more informed decisions while building trust (Mock et al., 2007). Therefore, it is expected that companies aiming for reduction of the information asymmetry (between management and other stakeholders) relating to carbon emissions and enhancement of the credibility of the reported 
climate change-related information, would like to have their climate change information assured, which would result in an increased level of corporate climate change disclosures. The above discussion leads to the formulation of the following hypothesis:

$H_{1}$ : External assurance of environmental information increases the level of corporate climate change disclosures.

\section{Research Methods}

\subsection{Sample and data}

For the purpose of testing the hypothesis, our sample includes 228 firm-year observations covering an eight-year period (2008-2015) for Finnish companies that were listed on the Nasdaq Helsinki at least for one year during this eight-year period and that responded to the CDP questionnaire at least once during the sample period. The total number of firm-year observations over the eight-year period included in the original sample was 296. The observations are screened on the basis of the criterion that a complete set of necessary data (e.g., financial/CCDS/external assurance/other) should be available. Observations not meeting this criterion are excluded. As a result of this selection process, the total final sample consists of 228 observations. The number of observations by year is provided in Table 2 . The lowest number of observations is 19 in 2008 and the highest number of observations is 36 in 2014. The CDP questionnaire underwent substantial changes during the period from 2003 to 2006; moreover, sustainability professionals were doubtful about the reliability of the information provided (Guenther et al., 2016; Kolk et al., 2008). As a result, the CDP had to further develop the climate-change questionnaire for enhancing the reliability of the data and the questionnaire did not undergo major changes after 2008 (Guenther et al., 2016). Hence, our sample period starts in 
2008. The sample period ends in 2015 as the CDP has migrated from number score system to letter score system in 2016 (CDP, 2016). From 2016, the responding companies, based on their assessment across four consecutive levels namely, (a) disclosure; (b) awareness; (c) management; and (d) leadership, are awarded any of the eight letter scores that range from A to D- (CDP, 2016). According to the new scoring system, a company receiving A or A- will be in the Leadership level and on the other hand, a company receiving D or D- will be in the Disclosure level (for details, please see Scoring Introduction 2016, CDP).

Data on climate change disclosure are extracted from CDP climate change reports on Nordic countries. Firm specific data are retrieved from Thomson Reuters DataStream database. The data on external assurance are retrieved from the corporate sustainability/environmental/social responsibility reports of the sampled firms.

\subsection{Variables}

\subsubsection{Dependent variable}

The Carbon Disclosure Project (CDP) is currently the main global reference as regards corporate climate change disclosure (Lee et al., 2015; Luo et al., 2012; Matisoff et al., 2012). In line with previous studies, we employ the CDP carbon disclosure score as a proxy for climate change disclosure score (CCDS) (Guenther et al., 2016; Prado-Lorenzo \& Garcia-Sanchez, 2010; Reid \& Toffel, 2009; Stanny, 2013). Globally over 4,000 companies are currently responding to the CDP questionnaire (Gonzalez-Gonzalez \& Ramírez, 2016). Based on the information provided by companies regarding four aspects of their climate change management namely, (i) risk and opportunities; (ii) emission accounting, verification, and trading; (iii) performance; and (iv) governance, companies are given a score that ranges from 0 (for no answers given) to 100 (for 
complete disclosure) (Gonzalez-Gonzalez \& Ramírez, 2016; Guenther et al., 2016). Any company that scores above 70 points is considered to have maintained transparency of the information provided and believed to be committed to the fight against climate change (Gonzalez-Gonzalez \& Ramírez, 2016). But the disclosure score measures only disclosure, not performance; for example, a company is awarded points for disclosing its GHG emissions, but not for the amount of emissions and hence, the carbon disclosure score is not affected by the actual amount of emissions (CDP, 2008; Guenther et al., 2016).

\subsubsection{Independent variable}

External assurance (EX_ASSUR) is the variable of interest in this research. EX_ASSUR is coded 1 for companies with independent third-party assurance of, at a minimum, climate change-related information and 0 for companies with unassured climate change-related information (Giannarakis et al., 2018; Braam et al., 2016; Moroney et al., 2012).

\subsubsection{Control variables}

In line with previous studies, this paper controls for the effect of a number of variables namely, firm size (FSIZE), profitability (PROF), leverage (LEV), industry (IND), asset age (ASST_AGE), growth (GRWTH) and research and development intensity (RNDINT).

Because larger firms have higher visibility than smaller ones (Udayasankar, 2008), they face increased public pressure and are subject to greater public scrutiny to show enhanced environmental responsiveness (Choi et al., 2013; Yunus et al., 2016). Consequently, they face an increased stakeholder demand for information on their environmental and social activities that affect the stakeholders' welfare (Andrikopoulos \& Kriklani, 2013). Hence, a number of previous studies used FSIZE as a proxy for organizational visibility in order to explain voluntary 
environmental disclosure (Brammer \& Pavelin, 2006; Choi et al., 2013; Henriques \& Sadorsky, 1999; Sharma \& Nguan, 1999). A positive association, as earlier studies suggest (for example, Déjean \& Martinez, 2009; Giannarakis et al., 2017; Monteiro \& Guzmán, 2010), is expected between FSIZE and CCDS. FSIZE is measured as the natural logarithm of total assets (Jaggi et al., 2018; Kılıç \& Kuzey, 2019).

Previous research suggests that firms in better financial condition (profitable firms) are more likely to voluntarily disclose environmental information because such disclosures are a means of portraying themselves as environmentally responsive (Cormier et al., 2005). In addition, Choi et al. (2013) argue that profitable firms afford to pay the costs of identifying, collecting and reporting the information relating to carbon emission. Therefore, a positive association is expected between PROF and CCDS. PROF is measured by return on assets (ROA) and calculated as the ratio of net income before extraordinary items to total assets (Clarkson et al., 2008; Jaggi et al., 2018).

The cases of the Exxon Valdez and BP oil spills, the Union Carbide chemical disaster, and American Electric Power's emissions litigation (Deegan et al., 2000; Smith et al., 2011) provide evidence on the fact that firms' financial stability may be affected by environmental issues. Moreover, firms are increasingly dependent on creditor funding (Rankin et al., 2011; Neu et al., 1998) and hence, creditors would expect highly leveraged firms to be socially and environmentally responsive and provide more extensive disclosure on their social and environmental activities (Roberts, 1992). Therefore, $L E V$ is expected to be positively connected to CCDS. LEV is measured by the debt to equity ratio (Jaggi et al., 2018). 
The findings of prior research reveal that firms in highly polluting industries (or environmentally sensitive industries) are likely to disclose more environmental information than those in low polluting industries (Chithambo \& Tauringana, 2014; Cho \& Patten, 2007; Peters \& Romi, 2015). Therefore, a positive linkage is expected between $I N D$ and $C C D S$. Following the existing literature (Patten, 2002a; Clarkson et al., 2008; Cho et al., 2014; Yunus et al., 2016), energy, utilities, transportation, pharmaceuticals, materials, mining and extractive, paper, chemicals, petroleum, metals, utilities and telecommunication industries are considered highly polluting industries. IND is a dichotomous variable that takes the value of 1 if a firm operates in a highly polluting industry and 0 otherwise (Cho et al., 2014; Yunus et al., 2016; Jaggi et al., 2018).

In the existing literature, arguments are found in favor of controlling for the effect of the age of assets. It is argued that newer assets are more environment friendly as they are less polluting (or cleaner) (Clarkson et al., 2008; De Villiers et al., 2011; De Villiers \& Van Staden, 2011). Therefore, firms owning newer assets will be better environmental performers than those with older assets (Clarkson et al., 2008; Cormier \& Magnan, 1999; Cormier et al., 2005). Hence, Cormier et al., (2005) argue further that the age of assets may be considered to be a proxy for corporate environmental performance. In line with this argument, it is expected that firms with newer assets will have a higher level of climate change disclosures. The ASST_AGE is calculated by the ratio of net property, plant and equipment to gross property, plant and equipment (Clarkson et al., 2008).

Clarkson et al. (2011) assert that firms with superior management capabilities are innovative and pursue proactive environmental strategies in order to avoid non-compliance with environmental regulations and associated environmental costs in the presence of intense environmental regulations. For example, innovative firms would add social and environmental attributes to their 
products for the purpose of product differentiation, and this process may require them to invest in research and development (R\&D) projects (Elsayed \& Paton, 2005; McWilliams \& Siegel, 2001). This study controls for innovation and employs RNDINT as a proxy for innovation and expects a positive association between RNDINT and CCDS. RNDINT is calculated as the ratio of total R\&D expenditures to annual net sales (Elsayed \& Paton, 2005). In addition, prior studies confirm that stakeholders and the market expect that fast-growing companies would investment more in environmental innovations (Al-Tuwaijri et al., 2004; Porter \& van der Linde, 1995, Skinner \& Sloan, 2002). Consequently, this study controls for the effect of GRWTH and expects a positive relationship between $G R W T H$ and CCDS. GRWTH is computed as a year-to-year percentage change in sales (Clarkson et al., 2011).

\subsubsection{Regression model}

In this research the following regression model has been estimated:

$$
\begin{gathered}
\operatorname{CCDS}_{i, t}=\beta_{0}+\beta_{1} E_{-} X_{-} \text {SSSUR }_{i, t}+\beta_{2} \text { FSIZE }_{i, t}+\beta_{3} P R O F_{i, t}+\beta_{4} L_{E V_{i, t}}+\beta_{5} A S S T_{-} A G E_{i, t}+ \\
\beta_{6} \text { RNDINT }_{i, t}+\beta_{7} \text { GRWTH }_{i, t}+\beta_{8} I N D_{i, t}+\beta_{9} Y E A R_{i, t}+\varepsilon_{i, t}
\end{gathered}
$$

where, $C C D S=$ climate change disclosure score (the CDP carbon disclosure score), $E X \_A S S U R=$ external assurance, $\quad F S I Z E=$ firm $\quad$ size, $\quad P R O F=$ profitability, $\quad L E V=$ leverage,

$G R W T H=$ growth, ASST_AGE=asset age, RNDINT=research and development intensity and $I N D=$ industry. We also control for year effects in our regression model. Table 3 presents the summary of the variables that are used in the regression model.

\section{Results and Discussion}

\subsection{Descriptive statistics and correlation matrix}


The descriptive statistics, reported in Table 4, reveals that CCDS has an average value of 71.12 and it ranges from 0 to 100 indicating a significant variation across the sample. The mean of the independent variable $E X \_A S S U R$ is 0.42 which suggests that about $42 \%$ of the firms belonging to our sample have purchased external assurance for their sustainability reports. The average values for the control variables ASST_AGE, FSIZE, RNDINT, LEV, GRWITH and PROF appear to be $0.40,6.42,0.02,2.39,0.01$ and 0.06 respectively. Moreover, the mean of the remaining control variable industry equals 0.71 implying that $71 \%$ of the sample firms belong to the environmentally sensitive industry.

Table 5 exhibits the correlations among the variables under study. These numbers suggest that the highest correlation is observed between $C C D S$ and $E X \_A S S U R$. More importantly, the association appears to be positive. Similar connections are also detected for the CCDS-FSIZE and CCDS-RNDINT pairs. Additionally, a significant negative linkage is seen between $C C D S$ and $A S S T \_A G E$. We also find that the correlations between $C C D S$ and other control variables are found to be insignificant. It is noteworthy that the correlations between assurance and different control variables are low. This is also true when pair-wise correlations among the control variables are taken into account. The variance inflation factors (VIF) for these variables further indicate the nonexistence of multicollinearity.

\subsection{Regression Analysis}

Table 6 displays the results of the fixed effects analysis of our proposed model. We consider the fixed effects model as the Hausman test indicates that random effects analysis is inappropriate for our data set. Our findings reveal that $E X \_A S S U R$ emerges as a major determinant of climate change disclosures as the corresponding coefficient is found to be statistically significant at $1 \%$ 
level ${ }^{8}$. It is further observed that $E X \_A S S U R$ has a positive impact on $C C D S$ which supports our hypothesis about the association between external assurance and the level of climate change disclosures. This result implies that firms having their climate change-related and other environmental information externally assured tend to have a higher level of carbon emissions disclosure.

This finding is consistent with that documented by Braam et al. (2016), Giannarakis et al. (2018), Hassan et al. (2019) and Moroney et al. (2012) and can be explained in the light of stakeholder-agency theory (Hill \& Jones, 1992). Stakeholder-agency theory suggests that an information asymmetry exists between corporate managers and other stakeholders because corporate managers have control over critical information of the firm and they are able to filter or distort such information before they communicate it to other stakeholders. Consequently, other stakeholders require a control mechanism that will enable them, through provision of an increased level of authentic, accurate and reliable information, to identify whether corporate managers are serving their (other stakeholders') interest. Such a situation necessitates the evolution of a wide range of institutional structures, which Hill \& Jones (1992) term 'monitoring structures' (Hodge et al., 2009; Jones \& Solomon, 2010; O’Dwyer et al., 2011). In the context of corporate climate change disclosures, external assurance can be seen as a monitoring structure that can prevent companies from manipulating diffusion of climate change information (hiding information about failure to formulate strategies to reduce GHG emissions, for example) (Giannarakis et al., 2018), improve the processes of collecting data relating to carbon emissions

\footnotetext{
${ }^{8}$ In order to examine the role of external assurance in explaining the level of climate change disclosure, we have estimated two additional models as well. One of these two models includes only EX_ASSUR as the independent variable, whereas the second model involves only the control variables. These findings, not reported here, indicate that the $\mathrm{R}^{2}$ statistic tends to increase substantially when $E X \_A S S U R$ is included in the model. For instance, as suggested by the results of the first model, EX_ASSUR alone can explain $24 \%$ of the total variation in the dependent variable. For the other model, on the other hand, all the control variables account for only $11 \%$ of the total variation in CCDS. Moreover, as shown in Table 6, the $\mathrm{R}^{2}$ statistic for the estimated model amounts to $32 \%$. The results of additional models are available on request.
} 
(Jones \& Solomon, 2010; O’Dwyer et al., 2011), discover material errors in and omissions of climate change-related information and thus increase the quantity of the information disclosed (Hodge et al., 2009).

The results of this study also indicate that external assurance potentially serves as an effective monitoring structure for Finnish companies causing them to disclose a high level of climate change-related information. This increasing trend towards climate change disclosure indicates that Finnish companies defer to the pressure of their stakeholders to be more accountable for the impact of their activities on the climate and that external assurance, as a monitoring structure, is likely to play a crucial role in making companies incorporate in their environmental/sustainability report all climate change-related disclosure items that are valuable to all stakeholder groups (both shareholders and non-shareholders) leading to an increase in the level of climate change disclosures ${ }^{9}$.

Among the control variables, only FSIZE seems to have a significant effect on CCDS. Other control variables appear to be insignificant. FSIZE has a positive coefficient that is statistically significant at $10 \%$ level. The positive coefficient of FSIZE suggests that larger firms, in comparison to smaller ones, disclose more information relating to climate change. This finding is consistent with prior research (e.g., Chithambo \& Tauringana, 2014; Eleftheriadis \& Anagnostopoulou, 2015; Freedman \& Jaggi, 2005; Gonzales-Gonzales \& Ramírez, 2016; Luo et al., 2012; Prado-Lorenzo et al., 2009; Stanny \& Ely, 2008). Larger firms are under greater stakeholder scrutiny (Patten, 2002b) because they undertake more activities that affect the

\footnotetext{
${ }^{9}$ Given that climate change-related disclosures should be prepared before seeking external assurance service of such disclosures, we reproduce the analysis of Table 6 by incorporating a lag of the independent variable (EX_ASSUR). These findings, exhibited in Table A2, are consistent with those reported in Table 6. The only discrepancy is that ASST_AGE is now significant, albeit at $10 \%$ level.
} 
natural environment and contribute to climate change (Knox et al., 2006). Consequently, stakeholders expect a higher level of disclosures from larger firms about their carbon performance and initiatives or strategies to limit the adverse effects of their business activities on the climate. Failure on the part of corporations to meet stakeholders' information need may cause stakeholders to doubt whether their interests are being served by corporate managers. This may, as stakeholder-agency theory suggests (Hill \& Jones, 1992), give rise to the possibility of stakeholders' exit from the contractual relationships with corporate managers; in other words, stakeholders may withdraw critical resources from firms and thus threaten their survival. Larger companies, due to the exit threat of stakeholders and subsequent loss of access to critical resources, disclose more climate change-related information compared to smaller firms.

\subsection{Results of endogeneity test}

One would expect that EX_ASSUR might be influenced by FSIZE, PROF and LEV. We attempt to address this endogeneity problem by employing an instrumental variable in a two-stage least square regression. In the first stage, we regress $E X \_A S S U R$ on FSIZE, PROF and $L E V$ and then store the residuals $\left(R E S I D \_E X \_A S S U R\right)$. In the second stage, the residuals are used in the main regression model instead of the actual values of $E X \_A S S U R$.

The results of the endogeneity test, exhibited in Table 7, suggest that the coefficient of RESID_EX_ASSUR is still positive and statistically significant at $1 \%$ level. In addition, the WuHausman test confirms that there is no endogeneity problem in our analysis.

\subsection{Robustness test}


For robustness check, the Tobit regression model has been employed. The Tobit regression can be utilized in this study as our dependent variable CCDS only ranges from 0 to 100 (Luo and Tang, 2014).

The results of the Tobit regression are shown in Table 8. These findings mirror those reported in Table 6. For instance, EX_ASSUR remains highly significant at $1 \%$ level and its impact on the level of $C C D S$ is still positive. In addition, FSIZE still has a significant positive effect on CCDS. One striking finding is the emergence of $A S S T \_A G E$ as an influential variable that has a negative impact on CCDS (statistically significant at $1 \%$ level). Older assets cause more pollution than newer assets. Therefore, the age of assets is a proxy for corporate environmental performance (Cormier et al., 2005).

The inverse relationship of $A S S T \_A G E$ with $C C D S$ indicates that firms with older assets (poor environmental performers) reveal more information relating to climate change compared with those with newer assets (better environmental performers). Since firms possessing older assets are more responsible for climate change (Liao et al., 2015), they are under greater stakeholder scrutiny (Patten, 2002b). Consequently, stakeholders expect a higher level of climate changerelated disclosures from these firms. Stakeholder-agency theory (Hill \& Jones, 1992) suggests that firms that are greater contributors to climate change (because of their poor environmental performance) may jeopardize their survival by failing to meet the information need of stakeholders because such failure may cause stakeholders to withdraw critical resources from these firms. Hence, firms with poor environmental performance in terms of actions against climate change (e.g., initiatives for reducing GHG emissions, initiatives for improving energy efficiency, use of clean energy sources etc.) are more likely to disclose a higher level of climate 
change-related information. This finding is consistent with earlier studies (e.g., Clarkson et al., 2008; Stanny \& Ely, 2008).

We observe further that the $\mathrm{R}^{2}$ statistic amounts to $60 \%$. Our results are robust as they are not sensitive to the models used.

\subsection{Additional tests}

\subsubsection{Logit regression analysis for the period 2016-2018}

As mentioned earlier, our sample period ends in 2015 due to the fact that the CDP has migrated from the number score system to the letter score system in 2016 (CDP, 2016). From 2016, the responding companies, based on their assessment across four consecutive levels namely, (a) disclosure; (b) awareness; (c) management; and (d) leadership, are awarded any of the eight letter scores that range from A to D- (CDP, 2016). According to the new scoring system, a company receiving A or A- will be in the Leadership level and on the other hand, a company receiving D or D- will be in the Disclosure level (for details, please see Scoring Introduction 2016, CDP $)^{10}$.

For the period 2016-2018, we estimate the ordered logit regression model to examine the impact of EX_ASSUR on the level of CCDS. The number of firm-year observations amounts to 67 for the ordered logit regression. We have adopted this model, as the observed dependent variable (i.e., $C C D S$ ) takes different values representing ordered or raked categories ${ }^{11}$. We define our dependent variable $C C D S$ as follows:

\footnotetext{
${ }^{10}$ Please see Appendix A for more details.

${ }^{11}$ Giannarakis et al. (2018) also employ the ordered logistic regression approach.
} 


$$
\text { CCDS }=\left\{\begin{array}{l}
1, \text { if the company receives } D \text { or } D- \\
2, \text { if the company receives } C \text { or } C- \\
3, \text { if the company receives } B \text { or } B- \\
4, \text { if the company receives } A \text { or } A-
\end{array}\right.
$$

The results of our additional analyses are exhibited in Table 9. These findings are also in line with those reported in Table 6. For instance, EX_ASSUR exerts a positive impact on the level of $C C D S$ and such effect remains statistically significant at $1 \%$ level. Besides, the coefficient of FSIZE is positive and weakly significant at $10 \%$ level. Overall, the findings of various regression analyses lead to the conclusion that there exists a positive linkage between $E X \_A S S U R$ and the level of $C C D S$, which suggests that companies having their environmental information externally assured seem to have a higher level of corporate climate change disclosures than those which have not. Hence, our results are robust as the analyses based on different sample periods lead to the same conclusion.

\subsubsection{Impact of 'type of assurance provider' and 'type of financial auditor'}

Carbon assurance is part of the broad-ranging sustainability assurance (Datt et al., 2019). Like the sustainability assurance market, the carbon assurance market is also comprised of two types of assurance providers (APs): accounting firms (ACCFs that include Big4 (KPMG, PricewaterhouseCoopers, Ernst \& Young and Deloitte)and other financial auditors) and nonaccounting firms (NACCFs that include, for example, specialist consulting firms) (Green et al., 2017; Wong et al., 2016; Zhou et al., 2016; Cohen \& Simnett, 2015; Green \& Taylor, 2013; Huggins et al., 2011).

These two groups of APs differ in expertise (Wong et al., 2016). For instance, ACCFs do not have specific scientific and engineering knowledge required for providing carbon and/or 
sustainability assurance (Green et al., 2017; Huggins et al., 2011; Delfgaauw, 2000) but they have a greater level of experience of providing assurance services. On the contrary, NACCFs have requisite knowledge and skills to provide GHG and/or sustainability assurance but they lack sufficient experience of providing assurance services. This important difference allows companies to choose between two types of APs (Green et al., 2017). But it is also noteworthy that Big4 accounting firms are currently controlling the sustainability assurance market (Fernandez-Feijoo et al., 2018; KPMG, 2013; Suddaby et al., 2007). Furthermore, it is evident from the existing literature that the level of sustainability disclosure is higher when the AP is a Big4 accounting firm (Fernandez-Feijoo et al., 2018; Zorio et al., 2013).

Therefore, in this section, we further our analysis by investigating the impact of two more variables on the level of climate change disclosure of assured firms. One of them is the 'Type of Assurance Provider' indicated by ASSUR_PRVDR, which is coded 1 for companies that have their carbon emissions disclosures assured by an ACCF (e.g., a Big4 or a non-Big4 financial auditor) and 0 for companies that purchase assurance from an NACCF (e.g., a specialist consulting firm). The second one is 'Type of Financial Auditor' represented by BIG4, which takes the value of 1 for companies that have hired one of the Big4 financial auditors to assure their carbon emissions disclosures and 0 otherwise. To serve this purpose, we estimate the following regression model:

$$
\begin{gathered}
C C D S_{i, t}=\beta_{0}+\beta_{1} \text { ASSUR_PRVDR }_{i, t}+\beta_{2} \text { BIG }_{i, t}+\beta_{3} \text { FSIZE }_{i, t}+\beta_{4} P_{R O F_{i, t}}+\beta_{5} L E V_{i, t}+ \\
\beta_{6} A S S T_{-} A G E_{i, t}+\beta_{7} R N D I N T_{i, t}+\beta_{8} G R W T H_{i, t}+\beta_{9} I N D_{i, t}+\beta_{10} Y E A R_{i, t}+ \\
\varepsilon_{i, t}
\end{gathered}
$$


Table 10 and Table 11 display the estimates of this analysis suggesting that neither ASSUR_PRVDR nor BIG4 has any impact on $C C D S$ as the parameters are found to be insignificant at conventional levels. These results are consistent with the Moroney et al. (2012) study that reports no association between the level of environmental disclosure and type of APs. But the outcomes contradict those reported by Fernandez-Feijoo et al. (2018) and Zorio et al. (2013) that confirm higher levels of sustainability disclosure when such disclosure is assured by a Big4 financial auditor.

\subsubsection{Impact of industry dummies}

So far, our empirical analyses show that the variable 'Industry (IND)' does not exert any significant effects on CCDS. It is worth mentioning that IND has been used as a dichotomous variable, taking the value of 1 if a company operates in a highly polluting industry and 0 otherwise. Now, in order to check the robustness of this finding, we classify the industry variable further and these new classifications include Financials (FIN), Consumer Discretionary (CONDIS), Consumer Staples (CONSTPL), Information Technology (IT), Telecommunications Services (TEL), Materials (MAT), Industrials (INDUST), Utilities (UTL), and Energy (NRG). Given that the number of observations appears to be very few for FIN, CONSTPL, TEL, UTL and NRG sectors, these segments form a new category named 'Others', which is used as a reference category. We then estimate the following regression to observe the impacts of these new industry dummies on CCDS:

$$
\begin{gathered}
\text { CCDS }_{i, t}=\beta_{0}+\beta_{1} E X_{-} \text {ASSUR }_{i, t}+\beta_{2} \text { FSIZE }_{i, t}+\beta_{3} P_{R O F_{i, t}}+\beta_{4} L E V_{i, t}+\beta_{5} A S S T_{-} A G E_{i, t}+ \\
\beta_{6} \text { RNDINT }_{i, t}+\beta_{7} \text { GRWTH }_{i, t}+\beta_{8} \text { CONDIS }_{i, t}+\beta_{9} I T_{i, t}+\beta_{10} \text { MAT }_{i, t}+\beta_{11} I N D U S T_{i, t}+ \\
\beta_{12} \text { YEAR }_{i, t}+\varepsilon_{i, t}
\end{gathered}
$$


Table 12 displays the estimates of Equation 3. It is evident from these findings that all the industry dummies except for CONDIS are found to be insignificant at conventional levels. CONDIS, however, appears to be significant only at $10 \%$ level. The results also reveal that EX_ASSUR and FSIZE still remain significant at $1 \%$ and $5 \%$ levels of significance, respectively. The finding that industry dummies have little or no impact on corporate climate change disclosures could be attributed to the fact that our sample includes companies from various sectors a positive effect in one industry may be cancelled out by a negative effect in another. Notably, this result is in line with Braam et al. (2016) who also document that industry dummies do not affect environmental performances.

\section{Conclusion and Policy Implications}

With the growing public awareness and concern about the global climate change, the demand for disclosure of information about climate change risks and climate change mitigation strategies by companies is also increasing. In order to enhance the reliability and credibility of the information reported and thus win stakeholders' confidence and subsequently build corporate reputation, companies are increasingly inclined to have their environmental information assured by independent assurance providers. While external assurance seems to impact the level of corporate climate change disclosures significantly, investigations of such association have not received much attention from researchers. In order to fill this vacuum in the existing literature, this research, using the lens of stakeholder-agency theory, examines the effect of external assurance on the extent of corporate climate change disclosures by Finnish firms.

The findings of our empirical analysis suggest that firms that have their environmental information externally assured have a higher level of climate change disclosures than firms that 
have not purchased such assurance. In other words, external assurance has a significant positive impact on the level of corporate climate change disclosures. A probable explanation for such an association between external assurance and the level of corporate climate change disclosures can be found in stakeholder-agency theory, which suggests that different institutional structures, referred to as monitoring structures, evolve in response to the tackling of the problem of information asymmetry between corporate managers and other stakeholders; in the context of corporate climate change disclosures, external assurance plays the role of such monitoring structure. As an effective monitoring structure, external assurance can improve companies' climate change-related data collection processes, can discover material errors in and omissions of the climate change-related information prepared, can prevent companies from manipulating diffusion of carbon information and thus can increase the level of corporate climate change disclosures (Hodge et al., 2009), which may potentially result in the reduction of information asymmetry between corporate managers and other stakeholders as far as climate change-related information is concerned. A number of control variables are used in this study and among them, mainly firm size and asset age are found to have significant effects on the level of corporate climate change disclosures.

The results of this study have implications for managers, investors, policy makers and regulators. By using the results of this research, corporate managers will be able to reduce the information asymmetry between various stakeholders and them through disclosure of accurate, reliable and credible environmental information. Such disclosures will, in turn, allow socially responsible investors to choose eco-friendly investments and will thus enable them to make appropriate investment decisions. Standardized carbon reports, which are produced in the presence of mandatory carbon reporting requirements, can provide extensive and reliable carbon information

\section{Page 36 of 71}


necessary for making investment decisions. Therefore, the findings of this study have implications for public policy-makers who may, in the absence of mandatory reporting requirements, develop standards for reporting corporate climate change-related information. Finally, the results of this study are important for regulators, who may serve as a watchdog on the transparency of firms' voluntary climate change-related disclosures. In case of companies' failure to disseminate accurate, reliable and credible climate change-related information, regulators may develop stringent rules and regulations to ensure that reliable disclosures are made by companies.

This research is subject to certain limitations. First, the source of the data used in this research is the CDP database which has limitations in that it is a voluntary disclosure process where all the observations collected are self-reported by the responding firms. This may bias the reported findings. Second, our sample includes only listed companies and hence the results might have limited explanatory capacity for unlisted firms. Third, the sample includes only the companies that have published sustainability reports. Fourth, this research is based solely upon Finnish data, which may inhibit the generalization of the findings in other contexts but this limitation can be overcome in future research by utilizing bigger samples that will include both local and international firms to provide greater understanding of how the voluntary adoption of external assurance affects the level of corporate climate change disclosures. Furthermore, countryspecific studies can also be conducted to facilitate the comparison of findings.

\section{References}


Abdel-khalik, A. R. 1993. Why do private companies demand an audit? A case for organizational loss of control. Journal of Accounting, Auditing \& Finance, 8 (1): 31-52.

Al-Tuwaijri, S., Christensen, T.E., \& Hughes II, K.E. 2004. The relations among environmental disclosure, environmental performance, and economic performance: a simultaneous equations approach. Accounting, Organizations and Society, 29 (5-6): 447-471.

Andrikopoulos, A., \& Kriklani, N. 2013. Environmental Disclosure and Financial Characteristics of the Firm: The Case of Denmark. Corporate Social Responsibility and Environmental Management, 20 (1): 55-64.

Appuhami, R., \& Tashakor, S. 2017. The impact of audit committee characteristics on CSR disclosure: an analysis of Australian firms. Australian Accounting Review, 27 (4): 400-420.

Ben-Amar, W., \& McIlkenny, P. 2015. Board effectiveness and the voluntary disclosure of climate change information. Business Strategy and the Environment, 24 (8): 704-719.

Ben-Amar, W., Chang, M., \& McIlkenny, P. 2017. Board gender diversity and corporate response to sustainability initiatives: evidence from the carbon disclosure project. Journal of Business Ethics, Vol. 142 (2): 369-383.

Blackwell, D. W., Noland, T. R., \& Winters, D. B. 1998. The value of auditor assurance: Evidence from loan pricing. Journal of Accounting Research, 36 (1): 57-70.

Brammer, S., \& Pavelin, S. 2006. Voluntary environmental disclosures by large UK companies. Journal of Business Finance \& Accounting, 33(7\&8): 1168-1188. 
Braam, G. J. M., Weerd, L. U. de, Hauck, M., \& Huijbregts, M. A. J. 2016. Determinants of corporate environmental reporting: the importance of environmental performance and assurance. Journal of Cleaner Production, 129: 724-734.

Braam, G., \& Peeters, R. 2018. Corporate Sustainability Performance and Assurance on Sustainability Reports: Diffusion of Accounting Practices in the Realm of Sustainable Development. Corporate Social Responsibility and Environmental Management, 25 (2): 164181.

Carbon Disclosure Project. (2008). Carbon Disclosure Project Report 2008, Global 500. Retrieved from https://www.pwc.co.uk/building-public-trustawards/assets/pdf/cdp_global_500_report_2008.pdf

Carbon Disclosure Project. 2016. Scoring introduction 2016. Retrieved from https://b8f65cb373b1b7b15febc70d8ead6ced550b4d987d7c03fcdd1d.ssl.cf3.rackcdn.com/cms/guidance_docs/pdfs/000/000/23 3/original/Scoring-Introduction-2016.pdf?1458064225

Carbon Disclosure Project. 2016. CDP Climate Change Report 2016 Nordic edition. Retrieved from http://www.ds-norden.com/public/dokumenter/CDPNordicclimatechangereport2016.pdf

Carey, P., Simnett, R., \& Tanewski, G. 2000. Voluntary demand for internal and external auditing by family business. Auditing: A Journal of Theory \& Practice, 19 (Supplement): 37-51.

Chithambo, L., \& Tauringana, V. 2014. Company specific determinants of greenhouse gases disclosures. Journal of Applied Accounting Research, 15 (3): 323-338. 
Choi, B.B., Lee, D., \& Psaros, J. 2013. An analysis of Australian company carbon emission disclosures. Pacific Accounting Review, 25 (1): 58-79.

Cho, C.H., \& Patten, D.M. 2007. The role of environmental disclosures as tools of legitimacy: a research note. Accounting, Organizations and Society, 32 (7-8): 639-647.

Cho, C.H., Guidry, R.P., Hageman, A.M., \& Patten, D.M. 2012. Do actions speak louder than words? An empirical investigation of corporate environmental reputation. Accounting, Organizations and Society, 37 (1): 14-25.

Cho, C. H., Michelon, G., Patten, D. M., \& Roberts, R. W. 2014. CSR report assurance in the USA: an empirical investigation of determinants and effects. Sustainability Accounting, Management and Policy Journal, 5 (2): 130-148.

Clarkson, P. M., Li, Y., Richardson, G. D., \& Vasvari, F. P. 2008. Revisiting the relation between environmental performance and environmental disclosure: An empirical analysis. Accounting, Organizations and Society, 33(4-5): 303-327.

Clarkson, P. M., Li, Y., Richardson, G. D., \& Vasvari, F. P. 2011. Does it really pay to be green? Determinants and consequences of proactive environmental strategies. Journal of Accounting and Public Policy, 30 (2): 122-144.

Clarkson, P., Li, Y., Richardson, G., \& Tsang, A. 2019. Causes and consequences of voluntary assurance of CSR reports: international evidence involving Dow Jones Sustainability Index inclusion and firm valuation. Accounting, Auditing \& Accountability Journal, 32 (8): 2451-2474.

Cohen, J., \& Simnett, R. 2015. CSR and assurance services: A research agenda. Auditing: A Journal of Practice \& Theory, 34 (1): 59-74. 
Comyns, B., \& Figge, F. 2015. Greenhouse gas reporting quality in the oil and gas industry: A longitudinal study using the typology of "search", "experience" and "credence" information. Accounting, Auditing \& Accountability Journal, 28 (3): 403-433.

Coram, P. J., Monroe, G. S., \& Woodliff, D. R. 2009. The value of assurance on voluntary nonfinancial disclosure: an experimental evaluation. Auditing: A Journal of Practice and Theory, 28 (1): $137-151$.

Cormier, D., \& Magnan, M. 1999. Corporate environmental disclosure strategies: Determinants, costs and benefits. Journal of Accounting, Auditing \& Finance, 14(4): 429-451.

Cormier, D., Magnan, M., \& Van Velthoven, B. 2005. Environmental disclosure quality in large German companies: Economic incentives, public pressures or institutional conditions? European Accounting Review, 14(1): 3-39.

Cotter, J., \& Najah, M. M. 2011. Institutional investor influence on global climate change disclosure practices. Australian Journal of Management, 37 (2): 169-187.

Cowen, S. S., Ferreri, L. B., \& Parker, L. D. 1987. The impact of corporate characteristics on social responsibility disclosure: A typology and frequency based analysis. Accounting, Organizations and Society, 12(2): 111-122.

Datt, R. R., Luo, L., \& Tang, Q. 2019. The impact of legitimacy threat on the choice of external carbon assurance: evidence from the US. Accounting Research Journal, 32 (2): 181-202.

De Villiers, C., \& Van Staden, C. 2006. Can less environmental disclosure have a legitimizing effect? Evidence from Africa. Accounting, Organizations and Society, 31 (8): 763-781. 
De Villiers, C., Naiker, V., \& Van Staden, C. J. 2011. The effect of board characteristics on firm environmental performance. Journal of Management, 37(6): 1636-1663.

De Villiers, C., \& Van Staden, C. J. 2011. Where firms choose to disclose voluntary environmental information. Journal of Accounting and Public Policy, 30(6): 504-525.

Deegan, C., Rankin, M., \& Voght, P. 2000. Firms' disclosure reactions to major social incidents: Australian evidence. Accounting Forum, 24(1): 101-130.

Déjean, F., \& Martinez, I. 2009. Environmental disclosure and the cost of equity: the French case. Accounting in Europe, 6 (1): 57-80.

Delfgaauw, T. 2000. Reporting on sustainable development: a preparer's view. Auditing, 19 (1): $67-74$.

Dixon, R., Mousa, G. A., \& Woodhead, A. D. 2004. The necessary characteristics of environmental auditors: a review of the contribution of the financial auditing profession. Accounting Forum, 28 (2): 119-138.

Eleftheriadis, I. M., \& Anagnostopoulou, E. G. 2015. Relationship between Corporate Climate Change Disclosures and Firm Factors. Business Strategy and the Environment, 24 (8): 780-789.

Elsayed, K., \& Paton, D. 2005. The impact of environmental performance on firm performance: static and dynamic panel data evidence. Structural Change and Economic Dynamics, 16 (3): $395-412$.

Eugénio, T.P., Lourenço, I.C., \& Morais, A.I. 2013. Sustainability strategies of company TimorL: extending the applicability of legitimacy theory. Management of Environmental Quality: An International Journal, 24 (5): 570-582. 
Fazzini, M., \& Maso, L. D. 2016. The value relevance of "assured" environmental disclosure: the Italian experience. Sustainability Accounting, Management and Policy Journal, 7 (2): 225245.

Fernandez-Feijoo, B., Romero, S., \& Ruiz, S. 2018. Financial auditor and sustainability reporting: does it matter? Corporate Social Responsibility and Environmental Management, 25 (3): 209-224.

Forsius, M., Anttila, S., Arvola, L., Bergstrom, I., Hakola, H., Heikkinen, H.I., Jelenius, J., Hyvarinen, M., Jylha, K., Karjalainen, J., Kaskinen, T., Laine, K., Nikinmaa, E., Letonen-Sainio, P., Rankinen, K., Reinikainen, M., Setala, H., Vuorenmaa, J. 2013. Impacts and adaptation options of climate change on ecosystem services in Finland: a model based study. Current Opinion in Environmental Sustainability, 5 (1): 26-40.

Freedman, M., \& Jaggi, B. 2005. Global warming, commitment to the Kyoto protocol, and accounting disclosures by the largest global public firms from polluting industries. The International Journal of Accounting, 40 (3): 215-232.

Giannarakis, G., Zafeiriou, E., \& Sariannidis, N. 2017. The impact of carbon performance on climate change disclosure. Business Strategy and the Environment, 26 (8): 1078-1094.

Giannarakis, G., Zafeiriou, E., Arabatzis, G., \& Partalidou, X. 2018. Determinants of corporate climate change disclosure for European firms. Corporate Social Responsibility and Environment Management, 25 (3): 281-294.

Gibson, R., \& Guthrie, J. 1995. Recent Environmental Disclosures in Annual Reports of Australian Public and Private Sector Organisations. Accounting Forum, 19 (2/3): 111-27. 
Gillet-Monjarret, C. 2012. A study of sustainability verification practices: the French case. Journal of Accounting \& Organizational Change, 8 (1): 62-84.

Gillet-Monjarret, C. 2015. Assurance of sustainability information: a study of media pressure. Accounting in Europe, 12 (1): 87-105.

Gillet-Monjarret, C. 2018. Assurance reports included in the CSR reports of French firms: a longitudinal study. Sustainability Accounting, Management and Policy Journal, 9 (5): 570-594.

Gonzalez-Gonzalez, J.M., \& Ramírez, C.Z. 2016. Voluntary carbon disclosure by Spanish companies: an empirical analysis. International Journal of Climate Change Strategies and Management, 8 (1): 57-79.

Gray, R.H., Kouhy, R., \& Lavers, S. 1995. Corporate social and environmental reporting: a review of the literature and a longitudinal study of UK disclosure. Accounting, Auditing \& Accountability Journal, 8 (2): 47-77.

Green, W., \& Li, Q. 2012. Evidence of an expectation gap for greenhouse gas emissions assurance. Accounting, Auditing \& Accountability Journal, 25 (1): 146-173.

Green, W., \& Taylor, S. 2013. Factors that influence perceptions of greenhouse gas assurance provider quality. International Journal of Auditing, 17 (3): 288-307.

Green, W., Taylor, S., \& Wu, J. 2017. Determinants of greenhouse gas assurance provider choice. Meditari Accountancy Research, 25 (1): 114-135.

Groening, C. J., \& Kanuri, V. K. 2013. Investor reaction to positive and negative corporate social events. Journal of Business Research, 66 (10): 1852-1860. 
Guenther, E., Guenther, T., Schiemann, F., \& Weber, G. 2016. Stakeholder relevance for reporting: explanatory factors of carbon disclosure. Business \& Society, 55(3): 361-397.

Guthrie, J., Cuganesan, S., \& Ward, L. 2008. Industry Specific Social and Environmental Reporting: The Australian Food and Beverage Industry. Accounting Forum, 32 (1): 1-15.

Guthrie, J., \& Farneti, F. 2008. GRI Sustainability Reporting by Australian Public Sector Organizations. Public Money and Management, 28 (6): 361-366.

Guthrie, J., \& Parker, L. D. 1989. Corporate Social Reporting: A Rebuttal of Legitimacy Theory. Accounting and Business Research, 19 (76): 343-352.

Haque, S., \& Deegan, C. 2010. Corporate Climate Change-Related Governance Practices and Related Dislosures: Evidence from Australia. Australian Accounting Review, 55 (20): 317-333.

Hasan, M., Roebuck, P., \& Simnett, R.2003. An investigation of alternative report formats for communicating moderate levels of assurance. Auditing A Journal of Practice and Theory, 22(2):171-187.

Hassan, A., Elamer, A. A., Fletcher, M., \& Sobhan, N. 2019. Voluntary assurance of sustainability reporting: evidence from an emerging economy. Accounting Research Journal, in press.

Henriques, I., \& Sadorsky, P. 1999. The relationship between environmental commitment and managerial perceptions of stakeholder importance. Academy of Management Journal, 42(1): 8799.

Hill, C. W. L., \& Jones, T. M. 1992. Stakeholder-agency theory. Journal of Management Studies, 29 (2): 131-154. 
Hodge, K., Subramaniam, N., \& Stewart, J. D. 2009. Assurance of sustainability reports: impact on report users' confidence and perceptions of information credibility. Australian Accounting Review, 19(3):178 - 194.

Hossain, M., Farooque, O. A., Momin, M. A., \& Almotairy, O. 2017. Women in the boardroom and their impact on climate change related disclosure. Social Responsibility Journal, 13 (4): 828855.

Huggins, A., Green, W., \& Simnett, R. 2011. The competitive market for assurance engagements on greenhouse gas statements: Is there a role for assurers from the accounting profession? Current Issues in Auditing, 5 (2): A1-A12.

Intergovernmental Panel on Climate Change. 2001. Summary for Policymakers Climate Change 2001: The Scientific Basis. Third Assessment Report. Geneva.

Intergovernmental Panel on Climate Change. 2007. The Physical Science Basis. Fourth Assessment Report. Valencia, Spain.

International Federation of Accountants. 2012. International Standard on Assurance Engagements (ISAE) 3410, Assurance Engagements on Greenhouse Gas Statements. Fiftieth Meeting of the International Auditing and Assurance Standards Board. Toronto, Canada.

Jaggi, B., Allini, A., Macchioni, R., \& Zagaria, C. 2018. The Factors Motivating Voluntary Disclosure of Carbon Information: Evidence Based on Italian Listed Companies. Organization \& Environment, 31(2): 178-202.

Jones, M. J. 2010. Accounting for the environment: Towards a theoretical perspective for environmental accounting and reporting. Accounting Forum, 34: 123-138. 
Jones, M., \& Solomon, J. 2010. Social and environmental report assurance: some interview evidence. Accounting Forum, 34 (1): 20-31.

Jones, P., Comfort, D., \& Hillier, D. 2015. Materiality and external assurance in corporate sustainability reporting: an exploratory study of UK house builders. Property Management, 33 (5): 430-450.

Junior R. M., Best P.J., \& Cotter J. 2014. Sustainability reporting and assurance: a historical analysis on a world-wide phenomenon. Journal of Business Ethics, 120 (1): 1-11.

Kalu, J.U., Buang, A., \& Aliagha, G.U. 2016. Determinants of voluntary carbon disclosure in the corporate real estate sector of Malaysia. Journal of Environmental Management, 182: 519-524.

Karamanou, I., \& Vafeas, N. 2005. The association between corporate boards, audit committees, and management earnings forecasts: an empirical analysis. Journal of Accounting Research, 43 (3): 453-486.

Kılıç, M., \& Kuzey, C. 2019. The effect of corporate governance on carbon emission disclosures: Evidence from Turkey. International Journal of Climate Change Strategies and Management, 11 (1): 35-53.

Knox, S., Maklan, S., \& French, P. 2006. Corporate social responsibility: exploring stakeholder relationships and programme reporting across leading FTSE companies. Journal of Business Ethics, 61 (1): 7-28.

Kolk, A., Levy, D., \& Pinkse, J. 2008. Corporate responses in an emerging climate regime: The institutionalization and commensuration of carbon disclosure. European Accounting Review, 17 (4): 719-745. 
KPMG. 2013. The KPMG survey of corporate responsibility reporting 2013. KPMG Global Sustainability Services, Amsterdam.

Lash, J., \& Wellington, F. 2007. Competitive advantage on a warming planet. Harvard Business Review, 85 (3): 94-102.

Lee, S.Y., Park, Y.S., \& Klassen, R.D. 2015. Market responses to firms' voluntary climate change information disclosure and carbon communication. Corporate Social Responsibility and Environmental Management, 22 (1): 1-12.

Liao, L., Luo, L., \& Tang, Q. 2015. Gender diversity, board independence, environmental committee and greenhouse gas disclosure. The British Accounting Review, 47: 409-424.

Liu, X., \& Anbumozhi, V. 2009. Determinant factors of corporate environmental information disclosure: an empirical study of Chinese listed companies. Journal of Cleaner Production, 17: 593-600.

Lozano, R., \& Huisingh, D. 2011. Inter-linking issues and dimensions in sustainability reporting. Journal of Cleaner Production, 19 (2-3): 99-107.

Lozano, R. 2015. A holistic perspective on corporate sustainability drivers. Corporate Social Responsibility and Environmental Management, 22 (1): 32-44.

Luo, L., Lan, Y. -C., \& Tang, Q. 2012. Corporate incentives to disclose carbon information: evidence from the CDP Global 500 report, Journal of International Financial Management \& Accounting, 23 (2): 93-120.

Luo, I., \& Tang, Q. 2014. Does voluntary carbon disclosure reflect underlying carbon performance? Journal of Contemporary Accounting \& Economics, 10 (3): 191-205. 
Luo, L. 2019. The influence of institutional contexts on the relationship between voluntary carbon disclosure and carbon emission performance. Accounting and Finance, 59 (2): 12351264.

Manetti, G., \& Toccafondi, S. 2012. The role of stakeholders in sustainability reporting assurance. Journal of Business Ethics, 107 (3): 363-377.

Marín, L., Rubio, A., \& de Maya, S.R. 2012. Competitiveness as a strategic outcome of corporate social responsibility. Corporate Social Responsibility and Environmental Management, 19 (6): 364-376.

Martinov-Bennie, N. 2012. Greenhouse gas emissions reporting and assurance: reflections on the current state. Sustainability Accounting, Management and Policy Journal, 3 (2): 244-251.

Matisoff, D.C., Noonan, D.S., \& O’Brien, J.J. 2012. Convergence in environmental reporting: assessing the carbon disclosure project. Business Strategy and The Environment, 22 (5): 285305.

McWilliams, A., \& Siegel, D. 2001. Corporate social responsibility: a theory of the firm perspective. Academy of Management Review, 26 (1): 117-127.

Mock, T., Strohm, C., \& Swartz, K. 2007. An examination of worldwide assured sustainability reporting. Australian Accounting Review, 17 (41): 67-77.

Monteiro, S. M. S., \& Guzmán, B. A. 2010. The influence of the Portuguese environmental accounting standard on the environmental disclosures in the annual reports of large companies operating in Portugal: a first view (2002-2004). Management of Environmental Quality: An International Journal, 21 (4): 414-435. 
Moroney, R., Windsor, C., \& Aw, Y.T. 2012. Evidence of assurance enhancing the quality of voluntary environmental disclosures: an empirical analysis. Accounting and Finance, 52 (3): 903-939.

Neu, D., Warsame, H., \& Pedwell, K. 1998. Managing public impressions: Environmental disclosures in annual reports. Accounting, Organizations and Society, 23(3), 265-282.

Nikolaeva, R., \& Bicho, M. 2011. The role of institutional and reputational factors in the voluntary adoption of corporate social responsibility reporting standards. Journal of Academy of Marketing, 39 (1): 136-157.

Niskala, M., \& Pretes, M. 1995. Environmental reporting in Finland: a note on the use of financial reports. Accounting, Organizations and Society, 20 (6): 457-466.

O’Donovan, G. 2000. Legitimacy theory as an explanation for corporate environmental disclosures. PhD thesis in Business, Victoria University of Technology, Melbourne.

O'Donovan, G. 2002. Environmental disclosure in the annual report: extending the applicability and predictive power of legitimacy theory. Accounting, Auditing \& Accountability Journal, 15 (3): 344-371.

O’Dwyer, B., Owen, D., \& Unerman, J. 2011. Seeking legitimacy for new assurance forms: the case of assurance on sustainability reorting. Accounting, Organizations \& Society, 36 (1): 31-52.

Othman, R., Nath, N., \& Laswad, F. 2017. Sustainability Reporting by New Zealand's Local Governments. Australian Accounting Review, 27 (3): 315-328.

Patten, D. M. 1991. Exposure, legitimacy and social disclosure. Journal of Accounting and Public Policy, 10 (4): 297-308. 
Patten, D. M. 2002a. The relation between environmental performance and environmental disclosure: A research note. Accounting, Organizations and Society, 27 (8): 763-773.

Patten, D.M. 2002b. Media exposure, public policy pressure, and environmental disclosure: an examination of the impact of TRI data availability. Accounting Forum, 26 (2): 152-171.

Peters, G. F., \& Romi, A. M. 2015. The association between sustainability governance characteristics and the assurance of corporate sustainability reports. Auditing: A Journal of Practice \& Theory, 34 (1): 163-198.

Pflugrath, G., Roebuck, P., \& Simnett, R. 2011. Impact of assurance and assurer's professional affiliation on financial analysts' assessment of credibility of corporate social responsibility information. Auditing: A Journal of Practice \& Theory, 30 (3): 239-254.

Porter, M.E., \& van der Linde, C. 1995. Green and competitive: ending the stalemate. Harvard Business Review, 73 (5):120-134.

Prado-Lorenzo, J.-M., Rodríguez-Domínguez, L., Gallego-Álvarez, I., \& García-Sánchez, I.-M. 2009. Factors influencing the disclosure of greenhouse gas emissions in companies world-wide. Management Decision, 47 (7): 1133-1157.

Prado-Lorenzo, J., \& Garcia-Sanchez, I. 2010. The role of the board of directors in disseminating relevant information on greenhouse gases. Journal of Business Ethics, 97 (3): 391-424.

Radhouane, I., Nekhili, M., Nagati, H., \& Paché, G. 2020. Is voluntary external assurance relevant for the valuation of environmental reporting by firms in environmentally sensitive industries? Sustainability Accounting, Management and Policy Journal, 11 (1): 65-98. 
Rankin, M., Windsor, C., \& Wahyuni, D. 2011. An investigation of voluntary corporate greenhouse gas emissions reporting in a market governance system: Australian evidence. Accounting, Auditing \& Accountability Journal, 24 (8): 1037-1070.

Reid, E. M., \& Toffel, M. W. 2009. Responding to public and private politics: Corporate disclosure of climate change strategies. Strategic Management Journal, 30 (11): 1157-1178.

Reimsbach, D., Hahn, R., \& Gürtürk, A. 2018. Integrated Reporting and Assurance of Sustainability Information: An Experimental Study on Professional Investors' Information Processing, European Accounting Review, 27 (3): 559-581.

Roberts, C. 1991. Environmental disclosures: a note on reporting practices in Mainland Europe. Accounting, Auditing and Accountability Journal, 4 (3): 62-71.

Roberts, R. W. 1992. Determinants of corporate social responsibility disclosure: An application of stakeholder theory. Accounting, Organizations and Society, 17 (6): 595-612.

Rossi, A., \& Tarquinio, L. 2017. An analysis of sustainability report assurance statements: evidence from Italian listed companies. Managerial Auditing Journal, 32 (6): 578-602.

Sellami, Y. M., Hlima, N. D. B., \& Jarboui, A. 2019. An empirical investigation of determinants of sustainability report assurance in France. Journal of Financial Reporting and Accounting, 17 (2): $320-342$.

Sharma, S., \& Nguan, O. 1999. The Biotechnology Industry and Strategies of Biodiversity Conservation: The Influence of Managerial Interpretations and Risk Propensity. Business Strategy and the Environment, 8 (1): 46-61. 
Simnett, R., Nugent, M., \& Huggins, A. 2009. Developing an international assurance standard on greenhouse gas statements. Accounting Horizons, 23 (4): 347-363.

Simnett, R., Vanstraelen, A., \& Chua, W. F. 2009. Assurance on sustainability reports: an international comparison. The Accounting Review, 84 (3): 937-967.

Skinner, D. J., \& Sloan, R. G. 2002. Earnings surprises, growth expectations, and stock returns or don't let an earnings torpedo sink your portfolio. Review of Accounting Studies, 7 (2-3): 289312.

Smith, L. C., Smith, L. M., \& Ashcroft, P. A. 2011. Analysis of environmental and economic damages from British Petroleum's Deepwater Horizon oil spill. Albany Law Review, 74 (1): 563585.

Stanny, E., \& Ely, K. 2008. Corporate Environmental Disclosures about the Effects of Climate Change. Corporate Social Responsibility and Environmental Management, 15 (6): 338-348.

Stanny, E. 2013. Voluntary disclosures of emissions by US firms. Business Strategy and the Environment, 22 (3): 145-158.

Suchman, M. C. 1995. Managing Legitimacy: strategic and institutional approaches. Academy of Management Review, 20 (3): 571-610.

Suddaby, R., Cooper, D. J., \& Greenwood, R. 2007. Transnational regulation of professional services: governance dynamics of field level organizational change. Accounting, Organizations and Society, 32 (4-5): 333-362.

Tagesson, T., Blank, V., Broberg, P., \& Collin, S. O. 2009. What explains the extent and content of social and environmental disclosures on corporate websites: a study of social and Page 53 of 71 
environmental reporting in Swedish listed corporations. Corporate Social Responsibility and Environmental Management, 16 (6): 352-364.

Thompson, P., \& Cowton, C. J. 2004. Bringing the environment into bank lending: Implications for environmental reporting. The British Accounting Review, 36 (2), 197-218.

Thornton, R. V., \& Hsu, S. 2001. Environmental management systems and climate change. Environmental Quality Management, 11 (1): 93-100.

Tyson, T., \& Adams, C. A. 2020. Increasing the scope of assurance research: new lines of inquiry and novel theoretical perspectives. Sustainability Accounting, Management and Policy Journal, 11 (2): 291-316.

Udayasankar, K. 2008. Corporate Social Responsibility and Firm Size. Journal of Business Ethics, 83 (2):167-175.

Van der Laan, G., Ees, H. V., \& Witteloostuijn, A. V. 2008. Corporate social and financial performance: an extended stakeholder theory, and empirical test with accounting measures. Journal of Business Ethics, 79 (3): 299-310.

Wallace, W. A. 1987. The economic role of the audit in free and regulated markets: a review. Research in Accounting Regulation, 1: 7-34.

Watts, R. L., \& Zimmerman, J. L. 1986. Positive Accounting Theory (Prentice Hall, New Jersey).

Weber, J. L. 2018. Corporate social responsibility disclosure level, external assurance and cost of equity capital. Journal of Financial Reporting and Accounting, 16 (4): 694-724. 
Wong, J., Wong, N., Li, W. Y., \& Chen, L. 2016. Sustainability assurance: an emerging market for the accounting profession. Pacific Accounting Review, 28 (3): 238-259.

Yunus, S., Evangeline, E.T., \& Abhayawansa, S. 2016. Determinants of carbon management strategy adoption: evidence from Australia’s top 200 publicly listed firms. Managerial Auditing Journal, 31 (2): 156-179.

Zhou, S., Simnett, R., \& Green, W. J. 2016. Assuring a new market: the interplay between country-level and company-level factors on the demand for greenhouse gas (GHG) information assurance and the choice of assurance provider. Auditing: A Journal of Practice \& Theory, 35 (3): 141-168.

Zorio, A., García-Benau, M. A., \& Sierra, L. 2013. Sustainability development and the quality of assurance reports: empirical evidence. Business Strategy and the Environment, 22 (7): 484-500. 


\begin{tabular}{|c|c|c|}
\hline \multicolumn{3}{|c|}{ Panel A: Studies examining company specific determinants of corporate climate change disclosures } \\
\hline Study & Sample \& Data & Findings \\
\hline Chithambo \& Tauringana, 2014. & $\begin{array}{l}210 \text { companies listed on the London Stock } \\
\text { Exchange. Data relate to the year } 2011 \text {. }\end{array}$ & $\begin{array}{l}\text { While larger firms having more financial slack and } \\
\text { belonging to environmentally sensitive industries have a } \\
\text { higher level of climate change disclosure, firms with high } \\
\text { leverage tend to disclose less information. }\end{array}$ \\
\hline Eleftheriadis \& Anagnostopoulou, 2015. & $\begin{array}{l}47 \text { firms listed on the Athens Stock } \\
\text { Exchange. Data relate to the period 2008- } \\
2011 .\end{array}$ & $\begin{array}{l}\text { Firm size and profitability have significant positive } \\
\text { impact on the level of corporate climate change } \\
\text { disclosure but industry type has insignificant impact on } \\
\text { the same. }\end{array}$ \\
\hline Freedman \& Jaggi, 2005. & $\begin{array}{l}120 \text { firms from } 20 \text { countries. Data relate to } \\
\text { the year } 2000 .\end{array}$ & $\begin{array}{l}\text { Larger firms belonging to environmentally sensitive } \\
\text { industries disseminate more climate change information. } \\
\text { In addition, firms domiciled in the countries that have } \\
\text { ratified the Kyoto Protocol have higher level of global } \\
\text { warming related disclosure compared to firms in other } \\
\text { countries. }\end{array}$ \\
\hline Giannarakis et al., 2017. & $\begin{array}{l}119 \text { large firms listed on the London Stock } \\
\text { Exchange. Data relate to the year } 2014 \text {. }\end{array}$ & $\begin{array}{l}\text { Firms with better environmental performance have } \\
\text { higher level of climate change disclosure. }\end{array}$ \\
\hline Giannarakis et al., 2018. & $\begin{array}{l}215 \text { companies of Bloomberg European } \\
500 \text { Index large firms listed on the London } \\
\text { Stock Exchange. Data relate to the year } \\
2014 \text {. }\end{array}$ & $\begin{array}{l}\text { External assurance of environmental information } \\
\text { increases the level of climate change disclosure. } \\
\text { Moreover, firms with better environmental performance } \\
\text { and a higher proportion of government ownership tend to } \\
\text { provide more information relating to climate change. }\end{array}$ \\
\hline
\end{tabular}




\begin{tabular}{|c|c|c|c|}
\hline \multicolumn{4}{|c|}{$\begin{array}{l}\text { Table 1: Prior studies (Continued) } \\
\text { Panel A: Studies examining company specific determinants of corporate climate change disclosures }\end{array}$} \\
\hline \multicolumn{2}{|c|}{ Study } & Sample \& Data & Findings \\
\hline \multicolumn{2}{|c|}{ Gonzales-Gonzales \& Ramírez, 2016.} & $\begin{array}{l}82 \text { Spanish companies that } \\
\text { responded to the CDP (2012) } \\
\text { questionnaire. Data relate to } \\
\text { the year } 2012 \text {. }\end{array}$ & $\begin{array}{l}\text { Larger firms with high financial risk are under high stakeholder } \\
\text { pressures and tend to disclose more climate change-related } \\
\text { information. }\end{array}$ \\
\hline \multicolumn{2}{|l|}{ Luo et al., 2012.} & $\begin{array}{l}291 \text { firms from the CDP } \\
\text { Global } 500 \text { Report, 2009. Date } \\
\text { relate to the year 2009. }\end{array}$ & $\begin{array}{l}\text { Larger companies are under more economic and institutional } \\
\text { pressures and tend to disclose more information on carbon emissions. }\end{array}$ \\
\hline \multicolumn{2}{|l|}{ Prado-Lorenzo et al., 2009.} & $\begin{array}{l}101 \text { largest firms from the } \\
\text { USA, Canada, Australia and } \\
\text { the EU. Data relate to the year } \\
2007 \text {. }\end{array}$ & $\begin{array}{l}\text { Firm size and market capitalization have been found to have } \\
\text { significantly positive effect on the level of climate change disclosure. }\end{array}$ \\
\hline \multicolumn{2}{|l|}{ Stanny \& Ely, 2008.} & $\begin{array}{l}494 \text { listed US companies } \\
\text { (chosen from S\&P 500). }\end{array}$ & $\begin{array}{l}\text { Firm size, previous year's disclosures and foreign sales significantly } \\
\text { and positively affect firms' decision to disclose climate change- } \\
\text { related information. }\end{array}$ \\
\hline \multicolumn{4}{|c|}{ Panel B: Studies examining the effect of corporate governance characteristics on corporate climate change disclosures } \\
\hline $\begin{array}{l}\text { Ben-Amar \& McIlkenny, } \\
2015 .\end{array}$ & \multicolumn{2}{|c|}{$\begin{array}{l}559 \text { firm-year observations from the } 200 \\
\text { firms covered in the CDP-Canada annual } \\
\text { survey. Data relate to the period from } \\
2008 \text { to } 2011 \text {. }\end{array}$} & $\begin{array}{l}\text { There is a positive association between board effectiveness and the } \\
\text { firm's carbon disclosure quality. }\end{array}$ \\
\hline Ben-Amar et al., 2017. & \multicolumn{2}{|c|}{$\begin{array}{l}541 \text { firm-year observations from the } 200 \\
\text { firms covered in the CDP Canada annual } \\
\text { Survey. Data relate to the period 2008- } \\
2014 \text {. }\end{array}$} & $\begin{array}{l}\text { The probability of voluntary climate change disclosure is higher for } \\
\text { companies with a higher number of women on boards. }\end{array}$ \\
\hline Choi et al., 2013. & \multicolumn{2}{|c|}{$\begin{array}{l}\text { The largest } 100 \text { companies listed on the } \\
\text { Australian Securities Exchange. Data } \\
\text { relate to the period from } 2006 \text { to } 2008 \text {. }\end{array}$} & $\begin{array}{l}\text { The quality of corporate governance is a key driver for corporate } \\
\text { climate change disclosures. }\end{array}$ \\
\hline Hossain et al., 2017. & \multicolumn{2}{|c|}{$\begin{array}{l}1,175 \text { firm-year observations from } 331 \\
\text { companies in } 33 \text { countries. Data relate to } \\
\text { the period from } 2011 \text { to } 2013 .\end{array}$} & $\begin{array}{l}\text { Firms with a higher number of women directors and a larger board } \\
\text { tend to provide more carbon emissions information. }\end{array}$ \\
\hline
\end{tabular}

Page 57 of 71 


\begin{tabular}{|l|l|l|}
\hline \multicolumn{1}{|c|}{ Table 1: Prior studies (Continued) } \\
\hline Panel B: Studies examining the effect of corporate governance characteristics on corporate climate change disclosures \\
\hline \multicolumn{1}{|c|}{ Study } & \multicolumn{1}{|c|}{ Sample \& Data } & \multicolumn{1}{c|}{ Findings } \\
\hline Jaggi et al., 2018. & $\begin{array}{l}671 \text { firm-year observations from the } \\
\text { firms listed on the Italian Stock } \\
\text { Exchange. Data relate to the period from } \\
2010 \text { to 2013. }\end{array}$ & $\begin{array}{l}\text { Existence of environmental committees, board independence and } \\
\text { institutional shareholdings has a strong positive effect on firms' } \\
\text { voluntary carbon disclosure decisions. The effect is even stronger for } \\
\text { firms operating in highly polluting industries. }\end{array}$ \\
\hline Kilıç \& Kuzey, 2018. & $\begin{array}{l}770 \text { firm-year observations from 154 } \\
\text { companies listed on the Borsa Istanbul. } \\
\text { Data relate to the period from 2011 to } \\
2015 .\end{array}$ & $\begin{array}{l}\text { Firms with a higher percentage of independent directors, a } \\
\text { sustainability committee and a higher number of foreign directors are } \\
\text { more likely to disclose carbon emissions information. }\end{array}$ \\
\hline Liao et al., 2015. & $\begin{array}{l}329 \text { largest UK companies included in } \\
\text { the 2011 CDP FTSE350 reports. }\end{array}$ & $\begin{array}{l}\text { The propensity and extent of disclosure of GHG information is higher } \\
\text { for the firms that have a higher percentage of female directors on the } \\
\text { board, greater board independence and an environmental committee. }\end{array}$ \\
\hline Rankin et al., 2011. & $\begin{array}{l}187 \text { firms listed on the Australian Stock } \\
\text { Exchange. Date relate to the year 2007. }\end{array}$ & $\begin{array}{l}\text { Larger companies having environmental management systems and } \\
\text { higher corporate governance quality are likely to voluntarily } \\
\text { disseminate information relating to climate change. }\end{array}$ \\
\hline Yunus et al., 2016. & $\begin{array}{l}893 \text { firm-year observations from 200 } \\
\text { companies listed on the Australian } \\
\text { Securities Exchange. Data relate to the } \\
\text { period from 2008 to 2012. }\end{array}$ & $\begin{array}{l}\text { Firms having an environmental committee, larger board size, greater } \\
\text { board independence and implementing an environmental management } \\
\text { system are more likely to adopt carbon management strategy. }\end{array}$ \\
\hline
\end{tabular}


Table 2: Sample selection

\section{Observations}

Initial sample per year

No. of yearly observations with

missing data

Final observations per year

\begin{tabular}{cccc}
\hline 2008 & 2009 & 2010 & 20 \\
\hline 37 & 37 & 37 & 37
\end{tabular}

(18)

(14)

(13)

(9)

(4)

(3)

(1)

(6)

Total observations 296

$\underline{\underline{19}} \quad \underline{\underline{23}}$

$\underline{\underline{24}}$

$\underline{\underline{28}}$

$\underline{\underline{33}}$

$\underline{\underline{34}}$

$\underline{\underline{36}}$

$\underline{\underline{31}}$

$\underline{\underline{228}}$ 


\section{Table 3: Definitions of the variables used}

Variable Definition

CCDS CDP carbon disclosure score.

EX_ASSUR A dummy variable which is equal to 1 if the sustainability or environmental report is externally assured and 0 otherwise.

FSIZE $\quad$ Firm size is the logarithm of the firm's year-end total assets.

PROF Profitability is the return on assets.

LEV Leverage is the ratio of year-end total debt to year-end total equity.

GRWTH Growth is the percentage of increase in yearly sales.

ASST_AGE Asset age is the ratio of net property, plant and equipment to gross property, plant and equipment.

RNDINT Research and development intensity is the ratio of research and development expenditure to net sales revenue.

IND A dummy variable, which is equal to 1 if the firm is in one of the highly polluting industries and 0 otherwise. 
Table 4: Descriptive statistics

\begin{tabular}{lcccc}
\hline Variable & Mean & Maxi. & Min. & Std. Dev. \\
CCDS & 71.12 & 100.00 & 0.00 & 23.92 \\
EX_ASSUR & 0.42 & & 0.49 \\
FSIZE & 6.42 & 7.58 & 5.19 & 0.57 \\
PROF & 0.06 & 0.61 & -0.09 & 0.07 \\
LEV & 2.39 & 74.37 & 0.00 & 10.34 \\
ASST_AGE & 0.40 & 0.72 & 0.17 & 0.12 \\
RNDINT & 0.02 & 0.19 & 0.00 & 0.03 \\
GRWTH & 0.01 & 0.69 & -0.63 & 0.17 \\
IND & 0.71 & & & 0.45 \\
\hline
\end{tabular}


Table 5: Pearson correlations

\begin{tabular}{|c|c|c|c|c|c|c|c|c|c|}
\hline & CCDS & EX_ASSUR & FSIZE & PROF & LEV & ASST_AGE & RNDINT & GRWTH & IND \\
\hline $\mathrm{CCDS}$ & 1.000000 & & & & & & & & \\
\hline EX_ASSUR & $\begin{array}{r}0.549869 \\
(0.0000)\end{array}$ & 1.000000 & & & & & & & \\
\hline FSIZE & $\begin{array}{r}0.318284 \\
(0.0000)\end{array}$ & $\begin{array}{r}0.381180 \\
(0.0000)\end{array}$ & 1.000000 & & & & & & \\
\hline PROF & $\begin{array}{r}-0.102594 \\
(0.1884)\end{array}$ & $\begin{array}{r}-0.192446 \\
(0.0130)\end{array}$ & $\begin{array}{r}-0.209960 \\
(0.0066)\end{array}$ & 1.000000 & & & & & \\
\hline LEV & $\begin{array}{r}0.040049 \\
(0.6084)\end{array}$ & $\begin{array}{r}-0.011753 \\
(0.8805)\end{array}$ & $\begin{array}{r}0.226670 \\
(0.0033)\end{array}$ & $\begin{array}{r}-0.149904 \\
(0.0539)\end{array}$ & 1.000000 & & & & \\
\hline ASST_AGE & $\begin{array}{r}-0.222850 \\
(0.0039)\end{array}$ & $\begin{array}{r}-0.104993 \\
(0.1782)\end{array}$ & $\begin{array}{r}0.113830 \\
(0.1442)\end{array}$ & $\begin{array}{r}0.000810 \\
(0.9917)\end{array}$ & $\begin{array}{r}-0.050098 \\
(0.5215)\end{array}$ & 1.000000 & & & \\
\hline RNDINT & $\begin{array}{r}0.199381 \\
(0.0100)\end{array}$ & $\begin{array}{r}0.209479 \\
(0.0068)\end{array}$ & $\begin{array}{r}0.069156 \\
(0.3760)\end{array}$ & $\begin{array}{r}0.030026 \\
(0.7010)\end{array}$ & $\begin{array}{r}-0.100403 \\
(0.1981)\end{array}$ & $\begin{array}{r}-0.211933 \\
(0.0061)\end{array}$ & 1.000000 & & \\
\hline GRWTH & $\begin{array}{r}-0.065195 \\
(0.4040)\end{array}$ & $\begin{array}{r}-0.036966 \\
(0.6363)\end{array}$ & $\begin{array}{r}-0.108028 \\
(0.1659)\end{array}$ & $\begin{array}{r}0.057027 \\
(0.4655)\end{array}$ & $\begin{array}{r}-0.001880 \\
(0.9808)\end{array}$ & $\begin{array}{r}0.114207 \\
(0.1429)\end{array}$ & $\begin{array}{r}-0.133757 \\
(0.0858)\end{array}$ & 1.000000 & \\
\hline IND & $\begin{array}{r}0.061175 \\
(0.4337)\end{array}$ & $\begin{array}{r}0.025662 \\
(0.7428)\end{array}$ & $\begin{array}{r}0.226897 \\
(0.0033)\end{array}$ & $\begin{array}{r}-0.254534 \\
(0.0009)\end{array}$ & $\begin{array}{r}0.118028 \\
(0.1299)\end{array}$ & $\begin{array}{r}0.212988 \\
(0.0059)\end{array}$ & $\begin{array}{r}-0.472469 \\
(0.000)\end{array}$ & $\begin{array}{r}0.026627 \\
(0.7335)\end{array}$ & 1.000000 \\
\hline
\end{tabular}


Table 6: Regression results

\begin{tabular}{|c|c|c|c|c|}
\hline Dependent variable & & & & \\
\hline Variable & Coefficient & Standard Error & t-Statistic & $p$-value \\
\hline Intercept & 7.91 & 30.73 & 0.26 & 0.79 \\
\hline EX_ASSUR & $24.32 * * *$ & 3.39 & 7.17 & 0.00 \\
\hline FSIZE & $9.80 *$ & 5.01 & 1.96 & 0.06 \\
\hline PROF & -9.67 & 20.65 & -0.46 & 0.64 \\
\hline LEV & -0.11 & 0.245 & -0.45 & 0.64 \\
\hline ASST_AGE & -27.44 & 16.65 & -1.64 & 0.11 \\
\hline RNDINT & 61.32 & 83.36 & 0.73 & 0.46 \\
\hline GRWTH & 3.94 & 7.15 & 0.55 & 0.58 \\
\hline IND & 1.88 & 6.70 & 0.28 & 0.77 \\
\hline Year fixed effects & Yes & & & \\
\hline $\mathrm{R}^{2}$ & & & & \\
\hline F-statistic & & & & \\
\hline
\end{tabular}


Table 7: Results of endogeneity test

\begin{tabular}{lcccc}
\hline \multicolumn{1}{c}{ Dependent variable CCDS } & & & & \\
Intercept & Coefficient & Standard Error & t-Statistic & $p$-value \\
RESID_EX_ASSUR & -46.20 & 31.03 & -1.49 & 0.13 \\
FSIZE & $24.86^{* * *}$ & 3.36 & 7.39 & 0.00 \\
PROF & $19.07 * * *$ & 4.93 & 3.87 & 0.00 \\
LEV & -12.57 & 20.41 & -0.62 & 0.53 \\
ASST_AGE & -0.15 & 0.25 & -0.63 & 0.53 \\
RNDINT & -26.64 & 16.69 & -1.60 & 0.11 \\
GRWTH & 95.16 & 82.39 & 1.16 & 0.25 \\
IND & 4.68 & 7.08 & & 0.66 \\
\hline R & 4.76 & 6.40 & 0.74 & 0.51 \\
F-statistic & & & &
\end{tabular}


Table 8: Results of Tobit model

\begin{tabular}{|c|c|c|c|c|}
\hline \multicolumn{5}{|c|}{ Dependent variable CCDS } \\
\hline Variable & Coefficient & Standard Error & z-Statistic & $p$-value \\
\hline Intercept & $32.59 *$ & 18.71 & 1.74 & 0.08 \\
\hline EX_ASSUR & $22.27 * * *$ & 3.41 & 6.53 & 0.00 \\
\hline FSIZE & $5.82 *$ & 3.06 & 1.90 & 0.06 \\
\hline PROF & 14.62 & 21.88 & 0.67 & 0.50 \\
\hline LEV & 0.02 & 0.15 & 0.12 & 0.90 \\
\hline ASST_AGE & $-38.39 * * *$ & 13.08 & -2.94 & 0.00 \\
\hline RNDINT & 76.13 & 52.48 & 1.45 & 0.14 \\
\hline GRWTH & -0.23 & 8.80 & -0.03 & 0.97 \\
\hline IND & 6.30 & 4.01 & 1.57 & 0.11 \\
\hline $\mathrm{R}^{2}$ & & & & \\
\hline
\end{tabular}

$* * * p<0.01 ; * * p<0.05 ; * p<0.10$. 
Table 9: Results of ordered logit regression analysis for the period 2016-2018

\begin{tabular}{|c|c|c|c|c|}
\hline \multicolumn{5}{|l|}{ Dependent variable CCDS } \\
\hline Variable & Coefficient & Standard Error & z-Statistic & $p$-value \\
\hline \multicolumn{5}{|c|}{ Threshold of the dependent variable } \\
\hline $2-$ Band $\mathrm{C}$ or $\mathrm{C}-$ & 2.47 & 2.42 & 1.02 & 0.31 \\
\hline 3 - Band B or B- & 3.83 & 2.42 & 1.58 & 0.11 \\
\hline $4-$ Band $\mathrm{A}$ or A- & $4.86 * *$ & 2.43 & 2.00 & 0.05 \\
\hline \multicolumn{5}{|c|}{ Independent and control variables } \\
\hline EX_ASSUR & $1.11 * * *$ & 0.36 & 3.09 & 0.00 \\
\hline FSIZE & $0.63 *$ & 0.37 & 1.73 & 0.08 \\
\hline PROF & 0.001 & 5.03 & 0.00 & 0.99 \\
\hline LEV & -0.24 & 0.47 & -0.51 & 0.61 \\
\hline ASST_AGE & 0.24 & 1.01 & 0.24 & 0.81 \\
\hline RNDINT & 1.81 & 5.14 & 0.35 & 0.72 \\
\hline GRWTH & -1.53 & 0.96 & -1.59 & 0.11 \\
\hline IND & -0.39 & 0.41 & -0.96 & 0.33 \\
\hline Pseudo- $^{2}$ & \multicolumn{4}{|c|}{0.16} \\
\hline LR-statistic & \multicolumn{4}{|c|}{$26.19 * * *$} \\
\hline
\end{tabular}

$* * * p<0.01 ; * * p<0.05 ; * p<0.10$. 
Table 10: Impact of Type of Assurance Provider and Type of Financial Auditor (OLS regression)

\begin{tabular}{|c|c|c|c|c|}
\hline \multicolumn{5}{|c|}{ Dependent variable CCDS } \\
\hline Variable & Coefficient & Standard Error & t-Statistic & $p$-value \\
\hline Intercept & 58.38 & 39.71 & 1.47 & 0.15 \\
\hline ASSUR_PRVDR & -6.87 & 11.58 & -0.59 & 0.55 \\
\hline BIG4 & 14.31 & 11.07 & 1.29 & 0.20 \\
\hline FSIZE & 6.09 & 6.43 & 0.94 & 0.35 \\
\hline PROF & 34.87 & 39.60 & 0.88 & 0.38 \\
\hline LEV & -0.05 & 0.28 & -0.19 & 0.84 \\
\hline ASST_AGE & -44.26 & 26.82 & -1.64 & 0.11 \\
\hline RNDINT & -11.07 & 92.81 & -0.11 & 0.91 \\
\hline GRWTH & 6.07 & 9.86 & 0.61 & 0.54 \\
\hline IND & -1.36 & 10.34 & -0.13 & 0.89 \\
\hline Year fixed effects & Yes & & & \\
\hline $\mathrm{R}^{2}$ & & & & \\
\hline F-statistic & & & & \\
\hline
\end{tabular}


Table 11: Impact of Type of Assurance Provider and Type of Financial Auditor (Logit regression)

Dependent variable CCDS

Variable

\section{Coefficient}

Standard Error

z-Statistic

$p$-value

Threshold of the dependent variable

2 - Band $\mathrm{C}$ or $\mathrm{C}$ -

$7.15^{*}$

3.82

1.87

0.06

3 - Band B or B-

5.30

5.78

0.91

0.36

4 - Band A or A-

7.33

5.85

1.25

0.21

Independent and control variables

\begin{tabular}{lllll} 
ASSUR_PRVDR & 0.97 & 1.47 & 0.66 & 0.50 \\
BIG4 & 1.08 & 1.26 & 0.85 & 0.39 \\
FSIZE & 0.81 & 0.79 & 1.03 & 0.30 \\
PROF & -5.73 & 12.24 & -0.46 & 0.64 \\
LEV & -0.66 & 1.02 & -0.64 & 0.51 \\
ASST_AGE & 2.07 & 2.86 & 0.72 & 0.46 \\
RNDINT & 1.89 & 10.26 & 0.18 & 0.85 \\
GRWTH & 0.19 & 3.43 & 0.06 & 0.95 \\
IND & 0.31 & 1.09 & 0.28 & 0.77 \\
\hline Pseudo-R & & & & \\
LR-statistic & & $24.88^{* * *}$ & & \\
\hline
\end{tabular}

$* * * p<0.01 ; * * p<0.05 ; * p<0.10$. 
Table 12: Effects of industry dummies

\begin{tabular}{|c|c|c|c|c|}
\hline \multicolumn{5}{|c|}{ Dependent variable CCDS } \\
\hline Variable & Coefficient & Standard Error & t-Statistic & $p$-value \\
\hline Intercept & $-11787.19 * * *$ & 888.44 & -13.27 & 0.00 \\
\hline EX_ASSUR & $7.16^{* * *}$ & 2.69 & 2.65 & 0.00 \\
\hline FSIZE & $10.75^{* *}$ & 4.68 & 2.30 & 0.02 \\
\hline PROF & -23.32 & 14.35 & -1.62 & 0.11 \\
\hline LEV & -0.04 & 0.21 & -0.20 & 0.83 \\
\hline ASST_AGE & -18.12 & 12.67 & -1.42 & 0.15 \\
\hline RNDINT & -122.62 & 84.30 & -1.45 & 0.14 \\
\hline GRWTH & 0.57 & 4.82 & 0.11 & 0.90 \\
\hline \multicolumn{5}{|l|}{ Industry dummies } \\
\hline CONDIS & -19.54 & 10.08 & -1.93 & 0.06 \\
\hline MAT & -4.75 & 9.20 & -0.51 & 0.60 \\
\hline IT & 14.76 & 13.21 & 1.12 & 0.26 \\
\hline INDUST & -7.85 & 9.01 & -0.87 & 0.38 \\
\hline Year fixed effects & Yes & & & \\
\hline $\mathrm{R}^{2}$ & \multicolumn{4}{|c|}{0.65} \\
\hline F-statistic & \multicolumn{4}{|c|}{$24.34 * * *$} \\
\hline
\end{tabular}




\section{Appendix A}

The final letter grade that a particular company receives is awarded based on the score obtained in the highest achieved level. For example, if company XYZ achieves $88 \%$ in Disclosure level, $76 \%$ in Awareness level and 65\% in Management level, it will finally receive a letter grade of B. If a company obtains less than $40 \%$ in its highest achieved level, its letter score will have a minus sign. For example, if company $\mathrm{ABC}$ achieves $76 \%$ in Disclosure level and $38 \%$ in Awareness level, it will finally receive a letter grade of C-. Note that a company must achieve over $75 \%$ in Leadership to be eligible for an A and thus be part of the A List, which represents the highest scoring companies. This is how the companies get ranked. Table A1 displays this ranking system.

Table A1: The ranking system

\begin{tabular}{|l|c|c|}
\hline \multirow{3}{*}{ Leadership } & $75-100 \%$ & A \\
\cline { 2 - 3 } & $0-74 \%$ & A- \\
\hline \multirow{3}{*}{ Management } & $40-74 \%$ & B \\
\cline { 2 - 3 } & $0-39 \%$ & B- \\
\hline \multirow{3}{*}{ Awareness } & $40-74 \%$ & C \\
\hline \multirow{2}{*}{ Disclosure } & $0-39 \%$ & C- \\
\hline & $40-74 \%$ & D \\
\hline
\end{tabular}


Table A2: Regression results with Lagged EX_ASSUR

\begin{tabular}{|c|c|c|c|c|}
\hline \multicolumn{5}{|l|}{ Dependent variable CCDS } \\
\hline Variable & Coefficient & Standard Error & t-Statistic & $p$-value \\
\hline Intercept & 5.88 & 31.95 & 0.18 & 0.85 \\
\hline Lagged EX_ASSUR & $20.57 * * *$ & 3.41 & 6.02 & 0.00 \\
\hline FSIZE & $11.23^{* *}$ & 5.16 & 2.17 & 0.03 \\
\hline PROF & -16.05 & 20.53 & -0.78 & 0.43 \\
\hline LEV & -0.13 & 0.24 & -0.52 & 0.59 \\
\hline ASST_AGE & $-30.44 *$ & 17.03 & -1.78 & 0.07 \\
\hline RNDINT & 53.30 & 83.77 & 0.63 & 0.53 \\
\hline GRWTH & 5.97 & 7.59 & 0.78 & 0.43 \\
\hline IND & -0.54 & 6.81 & -0.08 & 0.96 \\
\hline Year fixed effects & Yes & & & \\
\hline $\mathrm{R}^{2}$ & & & & \\
\hline F-statistic & & & & \\
\hline $\begin{array}{l}\text { Notes: This table present th } \\
C C D S_{i, t}=\beta_{0}+\beta_{1} E X_{-} \\
\beta_{6} R N D I N T_{i, t}+\beta_{7} G R V\end{array}$ & $\begin{array}{l}S S U R_{i, t-1}+ \\
T H_{i, t}+\beta_{8} I \Lambda\end{array}$ & $\begin{array}{l}\text { d from the followir } \\
F S I Z E_{i, t}+\beta_{3} P K \\
t+\beta_{9} Y E A R_{i, t}+\end{array}$ & $+\beta_{4} L E V_{i, t}$ & $\Gamma_{-} A G E_{i, t}+$ \\
\hline
\end{tabular}

